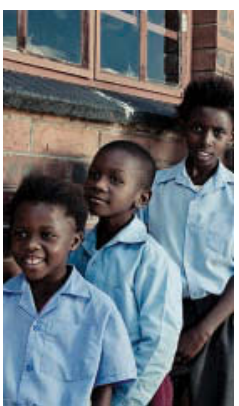

\title{
Child and Adolescent Health and Development: Realizing Neglected Potential
}

Donald A. P. Bundy, Nilanthi de Silva, Susan Horton, George C. Patton, Linda Schultz, and Dean T. Jamison

\section{INTRODUCTION}

It seems that society and the common legal definition have got it about right: it takes some 21 years for a human being to reach adulthood. The evidence shows a particular need to invest in the crucial development period from conception to age two (the first 1,000 days) and also during critical phases over the next 7,000 days. Just as babies are not merely small people-they need special and different types of care from the rest of usso growing children and adolescents are not merely short adults; they, too, have critical phases of development that need specific interventions. Ensuring that life's journey begins right is essential, but it is now clear that we also need support to guide our development up to our 21st birthday if everyone is to have the opportunity to realize their potential. Our thesis is that research and action on child health and development should evolve from a narrow emphasis on the first 1,000 days to holistic concern over the first 8,000 days; from an age-siloed approach to an approach that embraces the needs across the life cycle.

To begin researching and encouraging action, this volume, Child and Adolescent Health and Development, explores the health and development needs of the 5 to 21 year age group and presents evidence for a package of investments to address priority health needs, expanding on other recent work in this area, such as the Lancet Commission on Adolescent Health and Wellbeing
(Patton, Sawyer, and others 2016). Given new evidence on the strong connection between a child's education and health, we argue that modest investments in the health of this age group are essential to attain the maximum benefit from investments in schooling for this age group, such as those proposed by the recent International Commission on Financing Global Education Opportunity (2016). This volume shares contributors to both commissions and complements an earlier volume, Reproductive, Maternal, Newborn, and Child Health, which focuses on health in the group of children under age 5 years.

There is a surprising lack of consistency in the language used to describe the phases of childhood, perhaps reflecting the historically narrow focus on the early years. The neglect of children ages 5 to 9 years in particular is reflected in the absence of a commonly reflected name for this age group. Figure 1.1 illustrates the nomenclature used in this volume, which we have sought to align with the definitions and use outlined in the 2016 Lancet Commission on Adolescent Health and Wellbeing. The editors of this volume built upon the commission's definitions to include additional terms that are relevant to the broader age range considered here, including middle childhood to reflect the age range between 5 and 9 years. The editors also refer to children and adolescents between ages 5 and 14 years as "school-age," since in low- and lower-middleincome countries these are the majority of children in 


\section{Key Messages from Volume 8}

1. It takes 21 years (or 8,000 days) for a child to develop into an adult. Throughout this period, there are sensitive phases that shape development. Age-appropriate and condition-specific support is required throughout the 8,000 days if a child is to achieve full potential as an adult.

2. Investment in health during the first 1,000 days is widely recognized as a high priority, but there is historical neglect of investments in the next 7,000 days of middle childhood and adolescence. This neglect is also reflected in investment in research into these older age-groups.

3. At least three phases are critical to health and development during the next 7,000 days, each requiring a condition-specific and age-specific response:

- Middle Childhood Growth and Consolidation Phase (ages 5-9), when infection and malnutrition remain key constraints on development, and mortality rates are higher than previously realized

- Adolescent Growth Spurt (ages 10-14), when there is a major increase in body mass, and significant physiological and behavioral changes associated with puberty
- Adolescent Growth and Consolidation Phase (ages 15 to early 20s), bring further brain restructuring, linked with exploration and experimentation, and initiation of behaviors that are life-long determinants of health.

4. Broadening investment in human development to include scalable interventions during the next 7,000 days can be achieved cost-effectively at modest cost. Two essential packages were identified: the first addresses needs in middle childhood and early adolescence through a school-based approach; the second focuses on older adolescents through a mixed community and media and health systems approach. Both offer high cost-effectiveness and benefit-cost ratios.

5. Well-designed health interventions in middle childhood and adolescence can leverage the already substantial investment in education, and better design of educational programs can bring better health. The potential synergy between health and education is currently undervalued, and the returns on co-investment are rarely optimized.

Box 1.2

\section{Evolution of Disease Control Priorities and Focus of the Third Edition}

Budgets constrain choices. Policy analysis helps decision makers achieve the greatest value from limited resources. In 1993, the World Bank published Disease Control Priorities in Developing Countries (DCP1), which sought to assess systematically the cost-effectiveness (value for money) of interventions addressing the major sources of disease burden in low- and middle-income countries (Jamison and others 1993). The World Bank's World Development Report 1993 drew heavily on $D C P 1$ 's findings to conclude that specific interventions to combat noncommunicable diseases were cost-effective, even in environments with substantial burdens of infection and undernutrition (World Bank 1993).

$D C P 2$, published in 2006, updated and extended $D C P 1$ in several respects, giving explicit consideration to the implications for health systems of expanded intervention coverage (Jamison and others 2006). One way to expand coverage of health interventions is through platforms for interventions that require similar logistics but that address heterogeneous health problems. Platforms often provide a more natural unit for investment than do individual interventions, but conventional health economics 


\section{Box 1.2 (continued)}

has offered little understanding of how to make choices across platforms. Analysis of the costs of packages and platforms - and of the health improvements they can generate in given epidemiological environments — can help guide health system investments and development.

$D C P 3$ introduces the notion of packages of interventions. Whereas platforms contain logistically related sets of interventions, packages contain conceptually related ones. The 21 packages developed in the nine volumes of $D C P 3$ include surgery and cardiovascular disease, for example. In addition, $D C P 3$ explicitly considers the financial risk-protection objective of health systems. In populations lacking access to health insurance or prepaid care, medical expenses that are high relative to income can be impoverishing. Where incomes are low, seemingly inexpensive medical procedures can have catastrophic financial effects. DCP3 considers financial protection and the distribution across income groups as outcomes resulting from policies (for example, public finance) to increase intervention uptake and improve delivery quality. All of the volumes seek to combine the available science about interventions implemented in specific locales and conditions with informed judgment to reach reasonable conclusions about the effect of intervention mixes in diverse environments.
DCP3's broad aim is to delineate essential intervention packages-such as those for school-age children and adolescents, as outlined in this volume-and their related delivery platforms. This information is intended to assist decision makers in allocating often tightly constrained budgets and achieving health system objectives.

Four of DCP3's nine volumes were published in 2015 and 2016, and the remaining five will appear in 2017 or early 2018. The volumes appear in an environment in which serious discussion about quantifying and achieving the Sustainable Development Goals (SDGs) for health continues (United Nations 2015). DCP3's analyses are wellplaced to assist in choosing the means to attain the health SDGs and assessing the related costs. These volumes, and the analytic efforts on which they are based, will enable researchers to explore SDGrelated and other broad policy conclusions and generalizations. The final volume will report those conclusions. Each individual volume will provide specific policy analyses on the full range of interventions, packages, and policies relevant to its health topic.

Source: Dean T. Jamison, Rachel Nugent, Hellen Gelband, Susan Horton, Prabhat Jha, Ramanan Laxminarayan, and Charles N. Mock. primary school, owing to high levels of grade repetition, late entry to school, and drop outs. As income levels rise and secondary schooling enrollment increases, children attending school will be older than age 14 years. Figure 1.1 also demonstrates the overlap between many of these terms. For example, the Convention on the Rights of the Child defines child as every human being younger than age 18 years, whereas this volume defines adolescence as beginning at age 10 years and continuing through age 19 years (United Nations General Assembly 1989). Figure 1.1 also shows the alignment between age groups and four key phases critical to development. These key phases are used as an organizing principle for intervention throughout this volume. Where possible, the editors have extended the analyses to include children through age 21 years; but standard reporting of age data is in quintiles, so for convenience the editors have accepted the upper age range as $15-19$ years.
Some issues of potential importance to child development are examined in other volumes of $D C P 3$. For example, environmental issues are examined in some depth in volume 7 (Mock and others 2017), which examines the impact of pollution on health and human developmentespecially the exceptional prevalence of lead poisoning, which affects the intellectual development of children.

A premise of this volume is that human development occurs intensively throughout the first two decades of life (figure 1.1), and that for a person to achieve his or her full potential, age- and condition-specific interventions are needed throughout this 8,000 days (box 1.3). We use four key tools - cost-effectiveness, extended cost-effectiveness, benefit-cost, and returns on investment-to identify and prioritize investments at different ages and to propose delivery platforms and essential packages that are costed, scalable, and relevant to low-resource settings. These analyses suggest that public investment in health and development after age 5 years has been insufficient. 


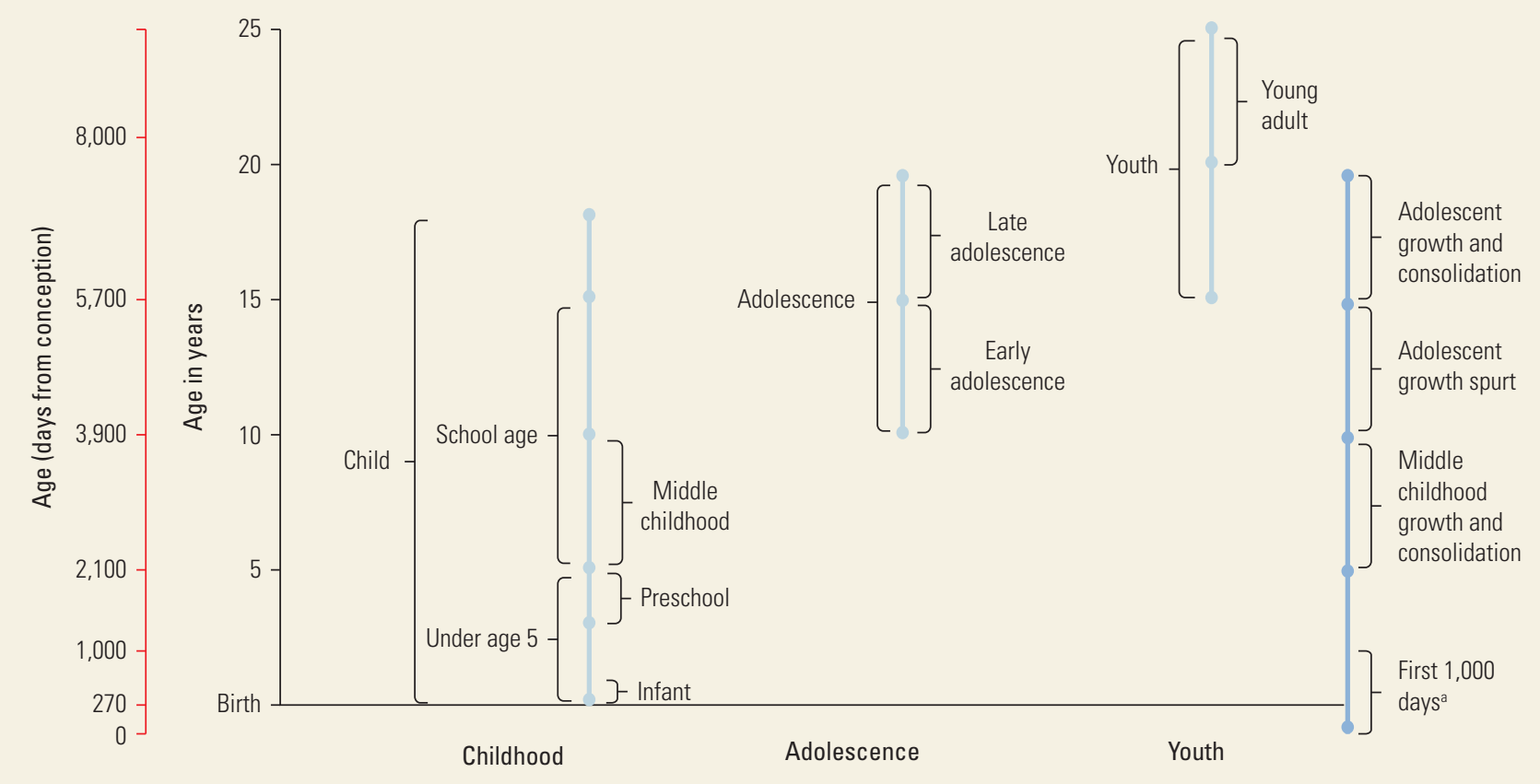

Note: a. The first 1000 days is typically measured from the time of conception, as is the 8,000 days that we discuss as the overall child and adolescent development period; other age-ranges presented here are measured from birth.

Box 1.3

\section{Early Childhood Development}

This volume takes a broad approach by examining child and adolescent health and development more generally, rather than focusing only on health. Therefore, although it focuses primarily on the 5-19 years age group, it also includes a discussion of early childhood development (ECD), which complements the discussion on early health in volume 2 .

The existence of key synergies justifies the inclusion of ECD in a series focused on health. These include synergies in the outcomes of different investments in children and synergies in the delivery of both sets of interventions.

Synergies in investments in children. Elsewhere in this chapter, we discuss the synergies between health and education for those ages 5-19 years. These same synergies are also important for young children. A pathbreaking study in Jamaica (Grantham-McGregor and others 1991) demonstrated that health and nutrition interventions alone are insufficient to address developmental deficits in young children facing multiple deprivations. Combining health and nutrition interventions with responsive stimulation was found to have short-term developmental benefits for growth and cognitive development not only in childhood but also into adulthood (Gertler and others 2014), with long-term effects on adult earnings and social outcomes.

Violence against children (child abuse) is an extreme negative example of the same synergy.

A systematic review (Norman and others 2012) documented how this extreme form of poor nurturing adversely affects physical and mental health. Child maltreatment and neglect are associated with substantial medical costs in childhood and adulthood 
Box 1.3 (continued)

(Brown, Fang, and Florence 2011; Fang and others 2015) and have negative impacts on adult economic well-being (CDC 2015; Currie and Widom 2010; Zielinski 2009). Although most of these studies are from high-income countries, similar results have been found in low- and middle-income countries.

Delivery platforms for early interventions at different ages. In the first 1,000 days, children's main contact with public sector institutions is with the health system, and it makes sense to use the health system to deliver education to parents about responsive stimulation. This education can be delivered through group sessions for parents at the local health facility or through home visits incorporating messages on responsive stimulation, as discussed in chapter 19 in this volume (Black, Gove, and Merseth 2017). Once children have received the required immunizations, they have fewer interactions with the health system; there are synergies then in using preschools and the school system to deliver health and nutrition interventions to children after age three years.
To date, the few published studies that have estimated the marginal additional cost of integrating programs for responsive stimulation into existing health services have found these costs to be modest (Horton and Black 2017, chapter 24 in this volume). However, these additional tasks cannot simply be loaded onto existing health workers without recognition of the need for additional training and supervision and for some increase in the ratio of health workers to population. Given the limited number of studies, it is not possible to estimate the economic returns to integrated programs.

An essential package for ECD. Chapter 24 in this volume (Horton and Black 2017) develops a basic ECD package relevant for low-income countries; the package focuses on parenting programs and encourages "responsive stimulation" (the positive interaction between a young child and his or her caregiver, with mutual benefit). These programs are estimated to cost US\$6 per child and are delivered in the first 1,000 days. As per capita incomes rise, preschool programs for children ages three to five years might be added.
Investment lags far behind the potential for return and is far below investments in health in the first five years and in primary education after age 5 years. Table $1.1 \mathrm{com}$ pares our recommendations for additional spending with current spending on education and with spending on health for children under age 5 years.

This bias in investment is paralleled by a similar bias in research. Approximately 99 percent of publications in Google Scholar and 95 percent in PubMed on the first 20 years of life focus on children under age 5 (annex 1A shows the number of publications since 2004 that our search found that include the terms health, mortality, or cause of death). The availability of age-specific publications reflects a lack of research funding for and attention to middle childhood and adolescence, resulting in a lack of data. The analysis for the Global Burden of Disease 2013 came to a similar conclusion, pointing out that most of the unique data sources for risk factors for adolescents ages 15-19 years were from school-based surveys, that children younger than age 5 had the most data available of any age group, and that adolescents ages 10-14 years had the fewest data sources (Mokdad and others 2016). The World Development Report 2007: Development and the Next Generation similarly found severe data shortcomings for these older age groups (World Bank 2006), whereas Hill and others found no empirical studies of mortality rates for the age group 5-14 years in countries without vital statistics, which include the majority of low- and middle-income countries (LIMCs) (Hill, Zimmerman, and Jamison 2017). The estimates, based on Demographic and Health Surveys Program data, reported here result in sharp upward adjustments in estimated numbers of deaths in that age range (Hill, Zimmerman, and Jamison 2017). This strong bias toward early childhood in the health literature may have been helpful in the successful United Nations Millennium Development Goals (MDG) drive to reduce under-five mortality. But it seems to have caused us to lose sight of the fact that the subsequent decades of growth and development in the transition to adulthood involve complex processes and critical periods that are sensitive to intervention.

This volume focuses on the scientific evidence, but local contexts, including culture, beliefs, lifestyles, and health systems, as well as other key determinants such as gender, race, ethnicity, sexuality, geography, socioeconomic status, and disability, are important for developing practical policies (Chandra-Mouli, Lane, and Wong 2015). 
Table 1.1 Estimates of Public Sector Investment in Human Development in Low- and Lower-MiddleIncome Countries

US\$, billions per year

\begin{tabular}{|c|c|c|c|}
\hline & $\begin{array}{l}\text { Low-income } \\
\text { countries }\end{array}$ & $\begin{array}{l}\text { Lower-middle- } \\
\text { income } \\
\text { countries }\end{array}$ & $\begin{array}{l}\text { Total for both low- } \\
\text { and lower-middle- } \\
\text { income countries }\end{array}$ \\
\hline \multicolumn{4}{|l|}{ Current spending } \\
\hline Basic education $^{\mathrm{a}}$ & 19 & 190 & 210 \\
\hline First 1,000 days $^{b}$ & 4.4 & 24 & 29 \\
\hline \multicolumn{4}{|l|}{ Proposed new package } \\
\hline School-age children package (excluding school feeding) & 0.13 & 0.38 & 0.51 \\
\hline School-age children package (including school feeding) ${ }^{c}$ & 0.47 & 2.8 & 3.3 \\
\hline Adolescent package ${ }^{c}$ & 0.88 & 2.7 & 3.6 \\
\hline $\begin{array}{l}\text { Total proposed spending on new packages in middle childhood and } \\
\text { adolescence (including school feeding)c }\end{array}$ & 1.4 & 5.5 & 6.9 \\
\hline \multicolumn{4}{|c|}{$\begin{array}{l}\text { These estimates are from The Learning Generation (International Commission on Financing Global Education Opportunity 2016, 37). They estimate current public sector spending } \\
\text { on basic (primary-level) education in low- and lower-middle-income countries. The report calls for increases to US } \$ 50 \text { billion and US } \$ 712 \text { billion, respectively, by } 2030 \text {. } \\
\text {. These estimates are from DCP3, volume } 2 \text { and are for the cost of two packages: (1) maternal and newborn and (2) under-five child health. The editors of volume } 2 \text { estimate } \\
\text { surrent spending in low- and lower-middle-income countries. Estimated incremental annual investments of US } \$ 7 \text { billion and US\$14 billion, respectively, are needed to } \\
\text { achieve full coverage. } \\
\text { These estimates are summarized in table 1.4. They are the estimated total cost of implementing the school-age and adolescent packages in low-and lower-middle-income }\end{array}$} \\
\hline
\end{tabular}

Some groups that tend to be marginalized and overlooked when planning intervention strategies, such as ethnic minorities, LGBT (lesbian, gay, bisexual, or transgender) youth, persons with disabilities, youth in conflict areas, and refugees, are also likely to have the greatest need for health and development support.

\section{A CONCEPTUAL FRAMEWORK FOR UNDERSTANDING CHILD AND ADOLESCENT HEALTH AND DEVELOPMENT}

In this volume, we develop a conceptual framework for exploring the processes and inputs that determine physical and cognitive growth from birth to adulthood (Bundy and Horton 2017, chapter 6 in this volume). The framework recognizes the importance of the first 1,000 days. It further notes that during the first two decades of life, there are at least three other critically important development phases: middle childhood (ages 5 to 9 years), the early adolescent growth spurt (ages 10 to 14 years), and the later adolescent phase of growth and consolidation (ages 15 to 19 years) when age-specific interventions are necessary. See figure 1.2.

Rates of physical growth are indeed at their highest at ages below age two, emphasizing the importance of the first 1,000 days. However, at the peak of the adolescent growth spurt, the growth rate for girls is similar to-and for boys exceeds - the rate at age two years and growth begins to occur in quite different ways (Tanner 1990). Furthermore, a review in chapter 8 in this volume (Watkins, Bundy, and others 2017) suggests that human growth remains relatively plastic throughout much of childhood, with potentially important amounts of catch-up growth. We need to be more careful about claiming that early insults are irreversible and recognize that more can be done to help older children catch up, especially in middle childhood. The data signal how unintended research bias and the scarcity of studies of ages 5-19 have had perverse policy consequences.

Evidence from neuroscience over the past 15 years suggests that critical phases of brain development occur beyond the first 1,000 days and in some cases long after. By age six years, the brain has reached approximately 95 percent of its adult volume, but size is not everything; rather, the connections within the brain are of growing importance through middle childhood and adolescence (Grigorenko 2017, chapter 10 in this volume). Different areas of the brain have different functions and develop at different rates. Peak development of the sensorimotor cortex - which is associated with vision, hearing, and motor control-occurs relatively early, and development is limited after puberty. The parietal and temporal association complex, responsible for language skills and numeracy, develops 
the fastest a little later; thus by about age 14 years, although it is possible to learn new languages, it is more difficult to speak a new language in the same way as a native speaker (Dahl 2004). The prefrontal cortex develops later still; this area is associated with higher brain functions, such as executive control (figure 1.2, panel b).

There is a sequence of brain development, and the kind of growth in middle childhood and adolescence differs from the kind of growth in early life. It is possible to see some of these differential growth rates in brain capabilities by studying the size of the subcortial regions as shown in figure 1.2, panel c (Goddings and others 2014).
The panel shows the pattern for adolescent boys. The patterns are similar for girls but occur at earlier ages because of different patterns of puberty. The panel shows that the regions associated with movement (such as the caudate and globus pallidus) are shrinking in size during early adolescence because these structures become more efficient as the functions become more mature. In contrast, regions associated with memory, decision making, and emotional reactions (amygdala and hippocampus) are still developing and growing in size during adolescence.

Brain development during infancy and early childhood is marked by the development of primary

Figure 1.2 Human Development to Age 20 Years
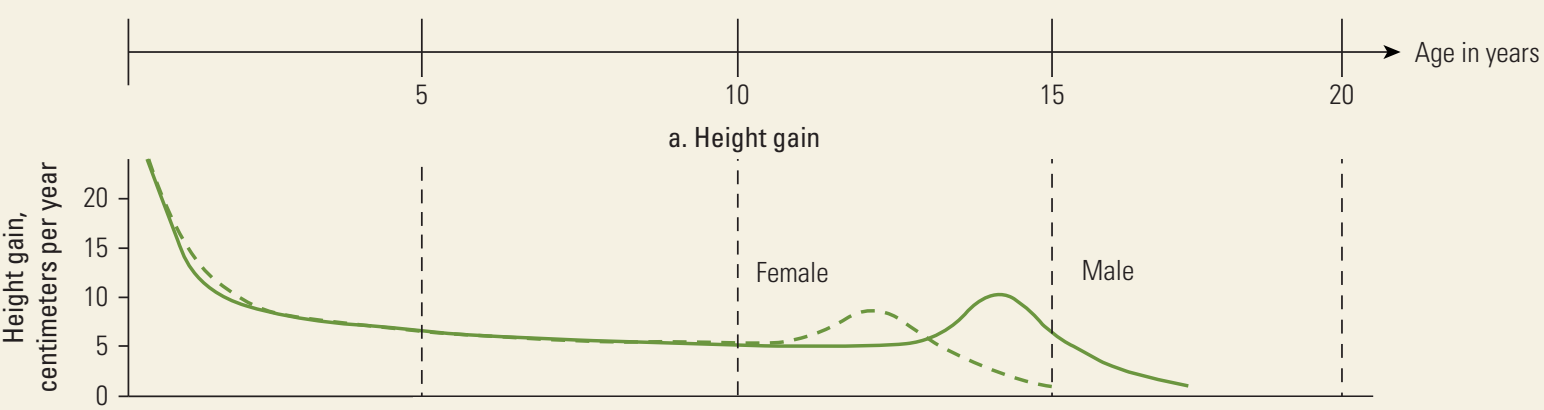

b. Change in brain development
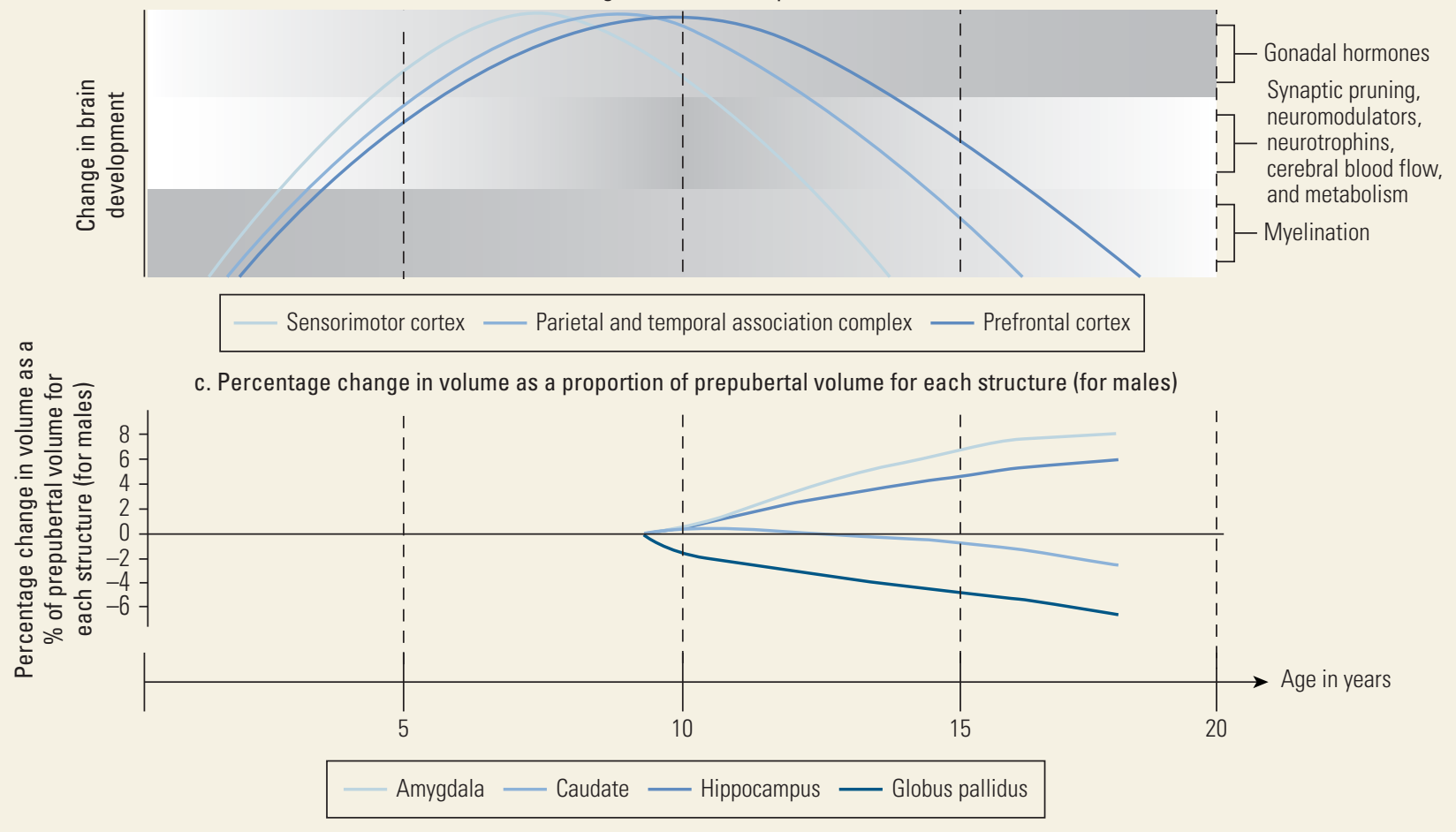

Sources: Adapted from Tanner 1990; Goddings and others 2014; Grigorenko 2017

Note: Behavioral attributes are paralleled by hormonal and neurobiological changes that target specific brain regions and cell populations (shown in shaded gray to capture the dynamic influences of hormones, various brain processes, and myelination). The vertical axis in panel b shows relative rate of growth of three brain areas from 0 to highest. The progressive shading indicates when the indicated activity is at its most intense (darkest shading). 
cognitive and emotional abilities. With the onset of the hormonal changes of puberty in middle childhood, a new phase of brain development commences in which the individual's interactions with the social, cultural, and educational environment shapes the processes of myelination and synaptic pruning of centers involved in emotional processing and higher executive functioning (Viner, Allen, and Patton 2017). Although primary cognitive abilities in stunted children may improve during middle childhood (Crookston and others 2013), brain development during these years and during adolescence is primarily focused on acquiring the higher-level cognitive, emotional, and social skills essential for functioning in complex social systems. As in earlier childhood, nutritional as well as social environments shape brain development (Andersen and Teicher 2008; Blakemore and Mills 2014).

Early intervention is critical for setting human development on an effective trajectory. However, the emphasis on the proposition that harm experienced in early life is irreversible is not only weakly supported by the evidence but also has led to an unfortunate lack of emphasis on exploring interventions later in childhood (Prentice and others 2013). Similarly, the widely cited conceptual framework of continuously declining rates of return with age (Heckmann 2011) is at variance with what is now known about the plasticity of brain development (Black, Gove, and Merseth 2017, chapter 19 in this volume) and of physical growth during much of middle childhood (Watkins, Bundy, and others 2017, chapter 8 in this volume), and it also fails to take into account the intergenerational benefits of actions in later childhood and adolescence. Some interventions make sense only at specific points in development; for example, some famous tennis players attribute their success to learning to play at age eight years, but they recognize that no amount of tennis lessons at age three would have achieved the same outcome. Current evidence suggests that there are substantial returns on investments made throughout the first two decades of life.

\section{THE UNFINISHED AGENDA OF MORTALITY REDUCTION}

During middle childhood and adolescence, the major consequences of ill health are related to morbidity rather than mortality. This fact does not mean that mortality is unimportant in older children. A new analysis of mortality was specifically conducted for this volume using Demographic and Health Surveys to estimate death rates for ages 5 to 19 years in the same way that data have been used to estimate rates for children under age 5 (Hill, Zimmerman, and Jamison 2017, chapter 2).

The estimates for 2010 suggest that the total annual mortality in LMICs in the 5 to 19 age group is around 2.3 million. The number of deaths estimated for children ages 5 to 9 years are 935,000, which is higher than the estimates of the United Nations Population Division and the Institute for Health Metrics and Evaluation (IHME) for this age group. Congruence of the new estimates with the UN and IHME data is closer for the 10 to 14 age group and closer yet for the 15 to 19 age group.

These results suggest that we need to do more to understand mortality in older children. A natural conclusion for policy would be to extend major national and international programmatic efforts that assess levels and causes of mortality in children under age 5 years to include the entire age range from birth through age 19 years. The United Nations Inter-agency Group for Child Mortality Estimation (IGME), which provides child mortality estimates through the Child Mortality Estimation (CME) database, and the Child Health Epidemiology Reference have historically focused on children under age 5 years, which helps explain why the data are so poor, and so poorly known, for children in middle childhood and adolescence. At least in part because of the focus in this volume on mortality levels in older children, IGME is expanding its work to cover this age range (Masquelin 2017). Although empirical estimates are still evolving, it is to be expected that IGME's effort will soon provide stable and up-to-date estimates that are country specific.

Morbidity is even more poorly documented than mortality for children over age five years. The volume explores the evidence for geographical and social differences in four key outcome measures-education, anthropometric status, micronutrient deficiency, and adolescent health - and describes major geographic variation in all four development outcomes (Galloway 2017; Wu 2017; Patton and others 2017, chapters 3-5, respectively, in this volume), but there is no systematic collection of morbidity data for this age-group, especially in LMICs. In exploring morbidity, we have begun to see that health and education are strongly linked in this age group; the education analysis shows that individual differences in health between students contribute to differences between educational outcomes and that differences in health are amenable to intervention in the short term.

\section{ESSENTIAL PACKAGES OF INTERVENTIONS FOR SCHOOL-AGE CHILDREN AND ADOLESCENTS}

Appropriate health interventions for the first 1,000 days are addressed in detail in volume 2 , which describes 
Table 1.2 Essential Package of Interventions for School-Age Children (Ages 5-14 Years)

\begin{tabular}{|c|c|c|c|c|c|}
\hline $\begin{array}{l}\text { Health } \\
\text { area }\end{array}$ & Population & Community & Primary health center & School & Benefit of delivering interventions in schools \\
\hline \multirow[t]{5}{*}{$\begin{array}{l}\text { Physical } \\
\text { health }\end{array}$} & \multirow[t]{5}{*}{-} & Deworming & Deworming & Deworming & $\begin{array}{l}\text { In endemic areas, regular deworming (following } \\
\text { WHO guidelines) can be done inexpensively in } \\
\text { schools now that the majority of deworming drugs } \\
\text { are donated; there are reported benefits in school } \\
\text { attendance as a result. }\end{array}$ \\
\hline & & $\begin{array}{l}\text { Insecticide- } \\
\text { treated net } \\
\text { promotion }\end{array}$ & $\begin{array}{l}\text { Insecticide-treated net } \\
\text { promotion }\end{array}$ & $\begin{array}{l}\text { Insecticide-treated } \\
\text { net promotion }\end{array}$ & $\begin{array}{l}\text { Education concerning the use of insecticide-treated } \\
\text { nets in endemic areas is important because } \\
\text { schoolchildren tend to use nets less often than do } \\
\text { mothers and small children. }\end{array}$ \\
\hline & & $\begin{array}{l}\text { Tetanus toxoid } \\
\text { and HPV } \\
\text { vaccination }\end{array}$ & $\begin{array}{l}\text { Tetanus toxoid and HPV } \\
\text { vaccination }\end{array}$ & $\begin{array}{l}\text { Tetanus toxoid and } \\
\text { HPV vaccination }\end{array}$ & $\begin{array}{l}\text { Schools can be a good venue for administering } \\
\text { tetanus boosters, which benefit not only young people } \\
\text { themselves but also babies born to those young women. }\end{array}$ \\
\hline & & \multirow[t]{2}{*}{$\begin{array}{l}\text { Oral health } \\
\text { promotion }\end{array}$} & $\begin{array}{l}\text { Oral health promotion } \\
\text { and treatment }\end{array}$ & $\begin{array}{l}\text { Oral health } \\
\text { promotion }\end{array}$ & $\begin{array}{l}\text { Education on oral health is important; poor } \\
\text { households generally cannot afford dental treatment. }\end{array}$ \\
\hline & & & $\begin{array}{l}\text { Vision screening } \\
\text { and provision of glasses }\end{array}$ & $\begin{array}{l}\text { Vision screening } \\
\text { and treatment }\end{array}$ & $\begin{array}{l}\text { Vision screening and provision of inexpensive ready- } \\
\text { made glasses boost school performance. }\end{array}$ \\
\hline \multirow[t]{3}{*}{ Nutrition } & \multirow[t]{3}{*}{-} & $\begin{array}{l}\text { Micronutrient } \\
\text { supplementation }\end{array}$ & - & $\begin{array}{l}\text { Micronutrient } \\
\text { supplementation }\end{array}$ & - \\
\hline & & $\begin{array}{l}\text { Multifortified } \\
\text { foods }\end{array}$ & - & Multifortified foods & - \\
\hline & & & & School feeding & $\begin{array}{l}\text { School meals promote attendance and education } \\
\text { outcomes. }\end{array}$ \\
\hline
\end{tabular}

Source: Fernandes and Aurino 2017 (chapter 25 in this volume).

Note: $-=$ not available; HPV = human papillomavirus; $\mathrm{WHO}=$ World Health Organization. School-age children do not regularly come in contact with the health system unless they seek treatment. With the remarkable success of the Millennium Development Goals in increasing school enrollment and participation and the continuing focus on universal education with the Sustainable Development Goals, it makes sense to use schools to promote health in this age group and to deliver preventive and curative health interventions. These interventions are affordable and also the highest priority, given their health and educational benefits. Table 1.4 presents the cost of components of the essential package of investments for school-age children.

two essential packages of interventions targeted at young children: one on maternal and newborn health and the other on child health. In volume 8, we complement these packages with an analysis of early childhood development (Alderman and others 2017; Black, Gove, and Merseth 2017; Horton and Black 2017; Horton and others 2017, chapters 7, 19, 24, and 26, respectively, in this volume). Our analysis suggests that there is significant value in adding "responsive stimulation" to these health packages (box 1.3). More detailed analysis of the cost and relative effectiveness of the early child development package is presented in chapter 2 of volume 9 (Watkins, Nugent, and others 2018).

This volume focuses on the three phases of development for those older than age five years: middle childhood growth and consolidation, the adolescent growth spurt, and adolescent growth and consolidation (figure 1.1). We argue that intervention during each of these stages is essential to enhanced survival and to effective development; in addition, each stage provides an opportunity to remedy earlier failures in development, at least to some extent.

First we discuss a package of interventions aimed at school-age children (see table 1.2); this package addresses both middle childhood growth and consolidation (ages 5-9 years) and the adolescent growth spurt (ages 10-14 years). We then discuss a package aimed at later adolescence, which addresses adolescent growth and consolidation (ages 15-19 years) (table 1.3). In practice, there is considerable overlap between the age groups able to benefit from these two packages, and both packages are required to cover the needs of adolescents from ages 10 to 19 years.

As illustrated in maps 1.1 and 1.2, school-age children and adolescents (that is, the age group of 5-19 years) together constitute a substantial proportion of the overall population of all countries, with the proportion greatest in the poorest countries: 17.2 percent of high-income countries and rising to 37.2 percent of low-income countries. The essential health and development 
Table 1.3 Essential Package of Investments for Adolescents (Ages 10-19 Years, Approximately)

\begin{tabular}{|c|c|c|c|c|c|}
\hline $\begin{array}{l}\text { Health } \\
\text { area }\end{array}$ & Population & Community & Primary health center & School & $\begin{array}{l}\text { Benefit of targeting interventions to } \\
\text { adolescents }\end{array}$ \\
\hline \multirow[t]{3}{*}{$\begin{array}{l}\text { Physical } \\
\text { health }\end{array}$} & $\begin{array}{l}\text { Healthy lifestyle } \\
\text { messages: } \\
\text { tobacco, alcohol, } \\
\text { injury, accident } \\
\text { avoidance, and } \\
\text { safety }\end{array}$ & $\begin{array}{l}\text { Adolescent- } \\
\text { friendly } \\
\text { health } \\
\text { services }\end{array}$ & $\begin{array}{l}\text { Adolescent-friendly health } \\
\text { services: provision of } \\
\text { condoms to prevent STIs, } \\
\text { provision of reversible } \\
\text { contraception, treatment } \\
\text { of injury in general and } \\
\text { abuse in particular, screening } \\
\text { and treatment for STIs }\end{array}$ & $\begin{array}{l}\text { Healthy lifestyle } \\
\text { education, } \\
\text { including accident } \\
\text { avoidance and } \\
\text { safety }\end{array}$ & $\begin{array}{l}\text { National media messages on healthy life choices } \\
\text { in formats designed to appeal to adolescents, } \\
\text { combined with national policy efforts to support } \\
\text { healthy choices (limiting access of adolescents to } \\
\text { products most harmful to their health) }\end{array}$ \\
\hline & $\begin{array}{l}\text { Sexual health } \\
\text { messages }\end{array}$ & - & - & $\begin{array}{l}\text { Sexual health } \\
\text { education }\end{array}$ & $\begin{array}{l}\text { Additional health education in schools aimed } \\
\text { at issues relevant to older ages, intended to } \\
\text { supplement messages for younger children in the } \\
\text { school-age package }\end{array}$ \\
\hline & & & & $\begin{array}{l}\text { Adolescent- } \\
\text { friendly health } \\
\text { services }\end{array}$ & $\begin{array}{l}\text { Provision of adolescent-friendly health services } \\
\text { within schools or within health care facilities in } \\
\text { ways that respect adolescent needs }\end{array}$ \\
\hline Nutrition & $\begin{array}{l}\text { Nutrition } \\
\text { education } \\
\text { messages }\end{array}$ & - & - & $\begin{array}{l}\text { Nutrition } \\
\text { education }\end{array}$ & - \\
\hline $\begin{array}{l}\text { Mental } \\
\text { health }\end{array}$ & $\begin{array}{l}\text { Mental health } \\
\text { messages }\end{array}$ & - & Mental health treatment & $\begin{array}{l}\text { Mental health } \\
\text { education and } \\
\text { counseling }\end{array}$ & - \\
\hline
\end{tabular}

Source: Horton and others 2017 (chapter 26 in this volume).

Note: - = not available; STI = sexually transmitted infection. Adolescents are the hardest group to reach because many are no longer in school and feel uncomfortable accessing health services predominantly designed for adults. They may fear lack of confidentiality, and in some cases (such as teen pregnancy) may be stigmatized by health care workers. The total costs of the school-age package are about US\$10 per child in the 5-14 years age group and US\$9 per adolescent in the 10-19 years age group. Table 1.4 presents the cost of components of the essential package of investments for adolescents.

packages for school-age children and adolescents have particular relevance in low- and lower-middle-income countries where the population that can benefit from these developmental interventions constitutes approximately one-third of the total population.

\section{Essential Package of Interventions for School-Age Children}

Health and nutrition programs targeted through schools are among the most ubiquitous for school-age children in LMICs. Since the inclusion of school health programs in the launch of Education for All in 2000, it is difficult to find a country that is not attempting to provide school health services at some level, although the coverage is often limited (Sarr and others 2017). The World Food Programme estimates that more than 360 million schoolchildren receive school meals every day (Drake and others 2017, chapter 12 in this volume), many of whom live in LMICs, and the World Health Organization (WHO) estimates that more than 450 million schoolchildren-more than half of the target population-are dewormed annually (Bundy, Appleby, and others 2017, chapter 13 in this volume) in nearly all LMICs. These largely public efforts are variable in quality and coverage, but the large scale of existing programs indicates a willingness by governments to invest in health as well as education for this age group.

The school system represents an exceptionally costeffective platform through which to deliver an essential package of health and nutrition services to this age group, as has been well documented in high-income countries (HICs) (Shackleton and others 2016). It is also increasingly equitable, especially because increases in primary enrollment and attendance rates, and narrowing of gender gaps, are among the greatest achievements of the Millennium Development Goals (Bundy, Schultz, and others 2017, chapter 20 in this volume). In LMICs with weak health systems, the education system is particularly well-situated to promote health among school-going children and adolescents who may not be reached by health services. There are typically more schools than health facilities in all income settings, 


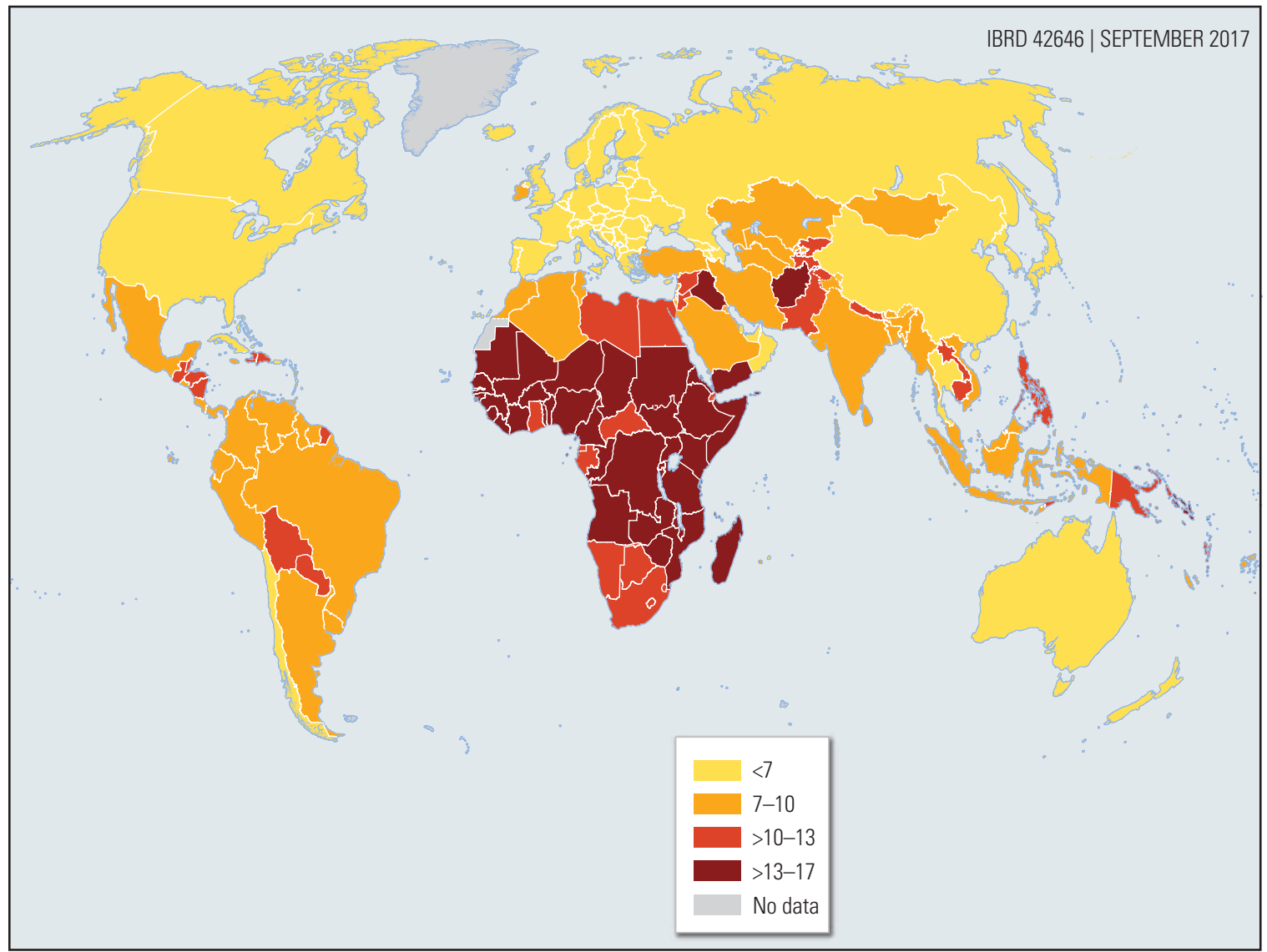

Source: United Nations, World Population Prospects: The 2015 Revision, July 2015.

and rural and poor areas are significantly more likely to have schools than health centers.

In this section, we examine the investment case for providing an integrated package of essential health services for children attending school in low- and lower-middleincome countries (see table 1.2). "School-age" includes both middle childhood and younger adolescence.

\section{Middle Childhood Growth and Consolidation Phase}

An important economic rationale for targeting the health and development of school-age children is to promote learning at an age when they have what may be their only opportunity to attend school. Ill health can be a catalyst for extended absence from or dropping out of school; for example, malaria and worm infections can reduce enrollment, and anemia resulting from malaria or worm infections can affect cognition, attention span, and learning (Benzian and others 2017; Brooker and others 2017; Bundy, Appleby, and others 2017; Drake and others 2017; LaMontagne and others 2017; Lassi, Moin, and Bhutta 2017 [chapters 11-16 in this volume]). Estimates suggest that in areas where malaria and worm infections are prevalent, poor students could gain the equivalent of 0.5 to 2.5 extra years of schooling if given appropriate health interventions, while sustaining benefits across multiple years of schooling could improve cognitive abilities by 0.25 standard deviation, on average. Extrapolating the benefits of improved accumulation of human capital could translate to roughly a 5 percent increase in earning capacity over the life course (Ahuja and others 2017, chapter 29 in this volume).

Chapter 8 in this volume (Watkins, Bundy, and others 2017) shows that some of these interventions also have important roles to play in maintaining and sustaining the gains of earlier investments, and children who slip through the early safety net can still achieve some catch-up growth with interventions in middle childhood. Furthermore, the new mortality analyses presented in chapter 2 (Hill, Zimmerman, and Jamison 2017) show that, for those ages five to nine years, survival continues to be a significant challenge, largely 


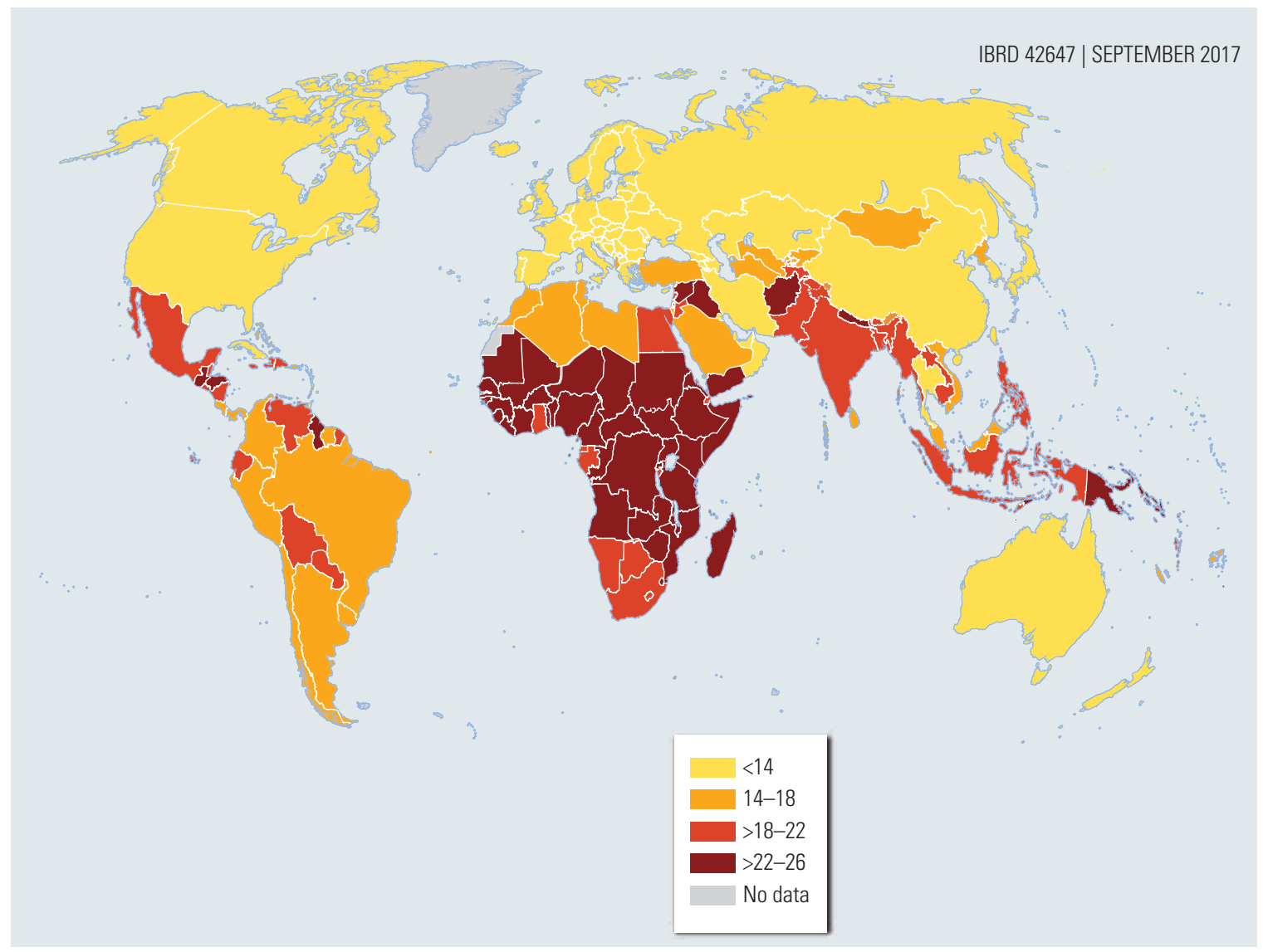

Source: United Nations, World Population Prospects: The 2015 Revision, July 2015.

because of the persistently high prevalence of infectious diseases, including pneumonia, diarrhea, and malaria. The control of infectious diseases therefore remains a critical element of intervention in this age group.

In many malaria-endemic areas, successful control programs have reduced the level of transmission substantially (Noor and others 2014; O'Meara and others 2008; WHO 2015). However, since the age pattern of clinical malaria is determined by the level of transmission and the consequent level of acquired immunity (Carnerio and others 2010; Snow and others 1997), clinical attacks of malaria are becoming more common in older children. In The Gambia, the peak age of hospital admission for severe malaria increased from 3.9 years in 1999-2003 to 5.6 years in 2005-2007 (Ceesay and others 2008); similar changes have been seen in Kenya (O'Meara and others 2008). This has created a new challenge for intervention, because none of the population-based presumptive treatment approaches are recommended for the school-age group and the current policy of testing and treating with Artemisinin-based combination therapy does not appear cost-effective in this age-group (Brooker and others 2017, chapter 14 in this volume; see also Babigumira, Gelband, and Garrison 2017, chapter 15 in volume 6). Analyses in this volume (Bundy, Appleby, and others 2017, chapter 13) and in volume 6 (Fitzpatrick and others 2017, chapter 16) also show that intestinal worm burdens are often greatest in school-age children, and whereas there is broad consensus on the benefits of treating infected children, there is controversy regarding the most cost-effective approach to school-based delivery. In practice, most countries use school-based mass treatment-that is, treatment of all children at risk, without prior screening. In 2015, more than 450 million children were treated, and India alone claims to have treated 340 million children in 2016 . 


\section{Adolescent Growth Spurt Phase}

The pubertal growth spurt is a watershed feature in the transition from childhood to adolescence, a process that occurs earlier for girls and that can be modified by external factors, including diet. The phase may provide the best opportunity for catch-up growth, with growth velocities reaching equivalence to those of children at age two years.

The growth spurt is a time of rapidly increasing muscle, bone, and organ mass, and of high dietary demand. One way of responding to this-providing meals in schools-is arguably the most prevalent publicly funded resource transfer program worldwide, with some 360 million children being fed every school day. A narrow focus on health outcomes underestimates the benefits of multiple cross-sectoral outcomes, including promoting school participation, especially for girls; providing a productive social safety net in hard-to-reach communities; and stimulating rural economies through the procurement of local produce (Drake and others 2017, chapter 12 in this volume). School feeding should be viewed as an option among other transfer programs with multiple outcomes. From a social perspectiveoften taken in economic evaluation-the net cost of a transfer is often close to zero, or the 10 percent to 15 percent of the total cost that is required for delivery (see discussion of the costs of cash and other transfer programs from multiple perspectives in chapter 23 in this volume, de Walque and others 2017). School feeding can thus be viewed as conditional (because school attendance triggers the transfer) non-cash transfer programs, and evaluations suggest that offering school meals typically increases attendance rates by 8 percent (Drake and others 2017). From this effect alone, benefit-cost ratios of 2 or more can be inferred.

School-based delivery of vaccination is particularly effective at this age, especially for girls. Tetanus toxoid vaccination lowers the risk of contracting tetanus both for recipients and for the children of adolescent girls, thus providing an intergenerational benefit. In addition, 70 percent coverage of human papillomavirus vaccine that is effective over a lifetime could avert more than 670,000 cases of cervical cancer in Sub-Saharan Africa over consecutive birth cohorts of girls vaccinated as young adolescents (LaMontagne and others 2017, chapter 15 in this volume). There is evidence that school-based vaccination programs can achieve effective coverage.

Early adolescence is the age when the most common vision problems - refractive errors-first emerge, and school-based screening of children in select grades is a cost-effective way to detect and correct refractive errors of vision that could otherwise increase the probability of dropping out of school, perhaps leading to lifelong visual impairment (Graham and others 2017, chapter 17 in this volume). Early adolescence is also a key phase for promoting lifelong healthy behaviors (World Bank 2006), including oral hygiene and good dietary practices. This phase may be particularly sensitive to diet, as it is associated with the emergence of micronutrient deficiency diseases, such as anemia and iodine deficiency.

\section{Essential Package of Interventions for Later Adolescence}

A phase of adolescent growth and consolidation begins around 15 years of age, continues into the 20s, and requires a package of age-specific interventions (table 1.3). This period has traditionally been viewed as socially important but has lacked concerted attention as a critical period for health and development. This is an age when self-agency becomes increasingly important, and although the concept of adolescent-friendly health services has been widely adopted, in reality the quality and coverage rarely respond to the need, in particular, ensuring that adolescents are able to make their own decisions about their health. School-based interventions that go beyond the teaching of health education in classrooms and encompass changes to the curriculum and the wider social environment, as well as engagement with families and the community, are more likely to improve sexual health, reduce violence, and decrease substance abuse (Reavley and others 2017, chapter 18 in this volume; Shackelton and others 2016). In the broader population, intersectoral action has been central to public health gains in many countries, including transport sector actions to reduce road traffic injuries and taxes to achieve tobacco control (Elvik and others 2009; Farrelly and others 2013).

With the exception of sexual and reproductive health, available evidence on preventive interventions derives largely from high-income countries and the United States in particular. The social and environmental determinants of adolescent health and well-being act at different levels and across different sectors. The most effective responses are likely to operate at multiple levels of particular settings (Viner and others 2012). The lives of young people are affected by community behavior and norms as well as by the values of adults and other adolescents. Community interventions have commonly involved local government, families, youth-focused and religious organizations, and schools.

Universal health coverage for adolescents requires training health care providers not only to respond to specific health problems beyond a focus on sexual and 
reproductive health but also to adopt nonjudgmental attitudes, to maintain confidentiality, and to engage with adolescents - while maintaining lines of communication with families. There needs to be a focus on addressing the financial barriers that are especially important for adolescents to overcome, such as making out-of-pocket payments and finding accessible platforms for health delivery that work for this age group. There is growing recognition of the importance of agency for this age group and of the importance of identifying approaches to health that enhance decision making and engagement of adolescents around their health and health care. Lack of adolescent agency is particularly common in LMICs.

Particularly for girls, the expansion of secondary education, which is one of the Sustainable Development Goals (SDGs) targeted for 2030, offers remarkable opportunities to improve health and well-being. Secondary education is effective in increasing the age at marriage and first pregnancy (Verguet and others 2017, chapter 28 in this volume). Participation in quality secondary education enhances cognitive abilities; improves mental, sexual, and reproductive health; lowers risks for later-life noncommunicable diseases; and offers significant intergenerational benefits (Blank and others 2010). Secondary schools also provide a platform for health promotion that can strengthen self-agency around health; provide essential health knowledge, including comprehensive sexuality education; and help to maintain lifestyles that minimize health risks. Equally, achieving the educational and economic benefits that secondary schools offer requires the avoidance of early pregnancy, infectious diseases, mental disorders, injury-related disabilities, and undernutrition.

Media messages have particular salience during the adolescent years and provide an essential platform for health action and have proven effective in HICs. Adolescents are biologically, emotionally, and developmentally primed for engagement beyond their families, and the media, particularly social media, offer that opportunity. Social media may also bring hazards, among the most conspicuous being online grooming, cyberbullying, and a growing preoccupation with body image, and so any intervention has to take these negatives into account (Durlak, Weissberg, and Dymnicki 2011; Farahmand and others 2011; Murray and others 2007).

\section{Economic Analysis of the Essential Packages}

Table 1.1 summarizes current levels of public investment in three important areas for child and adolescent health and development in LMICs: basic education (pre-primary, primary, and secondary), health in the first 1,000 days, and the two intervention packages for ages 5-19 years in low- and lower-middle-income countries. Table 1.4 summarizes the costs of the essential packages to promote health of school-age children and adolescents.

Of the three areas, education attracts the largest investment at US\$206 billion per year in 2015, much of which is from the public sector and is intended to provide pre-primary, primary, and secondary education free at the point of delivery. The International Commission on Financing Global Education Opportunity (2016) calls for governments to increase domestic public expenditures to support universal provision of primary education in lowand lower-middle-income countries by 2030, requiring an increase from 4.0 to 5.8 percent of gross domestic product (GDP), which is equivalent to an annual rate of growth in public education spending of 7 percent over a 15 -year period. In addition to education interventions, the commission identifies 13 nonteaching interventions as "highly effective practices to increase access and learning outcomes," including three health interventions: school feeding, malaria prevention, and micronutrient intervention. The achievement of universal secondary education by 2030 is a specific Sustainable Development Goal and is also cited in the report of the Lancet Commission on Adolescent Health and Wellbeing as key to adolescent growth and development.

In contrast to these very large public expenditures for education, the current annual investment for children younger than age five years is an estimated US\$28.6 billion, which includes investments in maternal and newborn health, as well as child health for children under age five years. It is estimated, based on current prices, that the cost of increasing coverage to 80 percent would be an additional US\$27.3 billion annually (table 1.1). This is based on estimates in volume 2 (Black, Walker, and others 2015) of the cost of the two packages: maternal and newborn health, and health of children under five.

For interventions in the health and development of children in the age range of 5-19 years in low- and lower-middle-income countries, we have no direct estimate of current expenditure. We present here the estimated total and incremental costs of providing a school-age package and an adolescent package to this age group (table 1.1). We estimate the total cost as US\$6.9 billion, comprising US\$1.4 billion and US $\$ 5.5$ billion in low- and lower-middle-income countries, respectively (not including HPV vaccination). Assuming that current provision is on the order of 20 percent to 50 percent of need, this implies an incremental need of between US $\$ 3.4$ billion and US\$5.4 billion annually, representing between 0.03 percent and 0.07 percent of GDP, dramatically less 
Table 1.4 Cost of Components of Essential Packages to Promote Health of School-Age Children and Adolescents in Low- and Lower-Middle-Income Countries

\begin{tabular}{|c|c|c|c|c|c|}
\hline Intervention & Mode of delivery & $\begin{array}{l}\text { Approximate cost per } \\
\text { child who benefits (US\$) } \\
\text { in low- and lower-middle- } \\
\text { income countries }\end{array}$ & $\begin{array}{l}\text { Approximate cost } \\
\text { per child (US\$) in } \\
\text { relevant age group }\end{array}$ & $\begin{array}{l}\text { Aggregate } \\
\text { cost in } \\
\text { low-income } \\
\text { countries } \\
\text { (US\$, millions, } \\
\text { per year) }\end{array}$ & $\begin{array}{l}\text { Aggregate } \\
\text { cost in lower- } \\
\text { middle-income } \\
\text { countries (US\$, } \\
\text { millions, per } \\
\text { year) }\end{array}$ \\
\hline \multicolumn{6}{|l|}{ School-age children } \\
\hline School feeding programs & $\begin{array}{l}\text { Meals (fortified with } \\
\text { micronutrients) provided at } \\
\text { school }\end{array}$ & $\begin{array}{l}41 \text { (targeted to } 20 \% \text { of } \\
\text { population in most food- } \\
\text { insecure or poor areas) }\end{array}$ & $\begin{array}{l}8.2 \text { per child ages } \\
\text { 6-12 years }\end{array}$ & 340 & 2,400 \\
\hline $\begin{array}{l}\text { Health education } \\
\text { (oral health, ITN use) }\end{array}$ & $\begin{array}{l}\text { ITN education delivered only } \\
\text { in endemic areas }\end{array}$ & $\begin{array}{l}0.50 \text { per educational message } \\
\text { (ITN message delivered only in } \\
\text { endemic areas; assumed } 50 \% \\
\text { of children in low- and lower- } \\
\text { middle-income countries) }\end{array}$ & $\begin{array}{c}0.75 \text { per child ages } \\
6-12 \text { years }\end{array}$ & 31 & 110 \\
\hline Vision screening & $\begin{array}{l}\text { Prescreening by teachers; } \\
\text { vision tests and provision of } \\
\text { ready-made glasses on site by } \\
\text { eye specialists }\end{array}$ & $\begin{array}{l}3.6 \text { per child to screen } \\
\text { and provide glasses to the } \\
\text { fraction of the age group } \\
\text { needing glasses }\end{array}$ & $\begin{array}{c}0.60 \text { per child ages } \\
6-12 \text { years }\end{array}$ & 25 & 90 \\
\hline Deworming & $\begin{array}{l}\text { Medication for soil-transmitted } \\
\text { helminths or schistosomiasis } \\
\text { delivered by teachers once a } \\
\text { year in endemic areas }\end{array}$ & $\begin{array}{l}0.70 \text { per child; } 50 \% \text { of } \\
\text { endemic areas }\end{array}$ & $\begin{array}{c}0.35 \text { per child ages } \\
6-12 \text { years }\end{array}$ & 14 & 52 \\
\hline Tetanus toxoid booster & $\begin{array}{l}\text { Single-dose booster } \\
\text { administered to all children in } \\
\text { one grade by nurse or similar } \\
\text { health care worker }\end{array}$ & 2.4 per child & $\begin{array}{c}0.40 \text { per child ages } \\
6-12 \text { years }\end{array}$ & 16 & 59 \\
\hline HPV vaccine & $\begin{array}{l}\text { Part of the cancer essential } \\
\text { package }\end{array}$ & $\begin{array}{l}10 \text { per fully vaccinated girl } \\
\text { (Gavi-eligible countries) }\end{array}$ & $\begin{array}{c}0.83 \text { per child ages } \\
6-12 \text { years }\end{array}$ & 43 & 74 \\
\hline $\begin{array}{l}\text { Aggregate costs } \\
\text { without HPV vaccine }\end{array}$ & & 48 & 10 & 430 & 2,700 \\
\hline $\begin{array}{l}\text { Aggregate costs without } \\
\text { school feeding programs } \\
\text { but with HPV vaccine }\end{array}$ & & 17 & 2 & 130 & 390 \\
\hline \multicolumn{6}{|l|}{ Adolescents } \\
\hline $\begin{array}{l}\text { Media messages on } \\
\text { national policy regarding } \\
\text { health }\end{array}$ & $\begin{array}{l}\text { Messages concerning use of } \\
\text { tobacco, alcohol, and illicit } \\
\text { drugs; sexual and reproductive } \\
\text { health; mental health; healthy } \\
\text { eating or physical activity }\end{array}$ & 1 per adolescent & $\begin{array}{l}1 \text { per adolescent } \\
\text { ages } 10-19 \text { years }\end{array}$ & - & - \\
\hline $\begin{array}{l}\text { Health education in } \\
\text { schools }\end{array}$ & $\begin{array}{l}\text { Education for targeted age } \\
\text { group }\end{array}$ & $\begin{array}{l}9 \text { per year per adolescent } \\
\text { ages } 14-16 \text { years }\end{array}$ & $\begin{array}{l}3 \text { per adolescent } \\
\text { ages } 10-19 \text { years }\end{array}$ & 90 & 450 \\
\hline $\begin{array}{l}\text { Adolescent-friendly } \\
\text { health services }\end{array}$ & $\begin{array}{l}\text { Health services offering } \\
\text { respectful and confidential } \\
\text { access for adolescents }\end{array}$ & 5 per adolescent & $\begin{array}{l}5 \text { per adolescent } \\
\text { ages } 10-19 \text { years }\end{array}$ & 790 & 2,300 \\
\hline Aggregate costs & & $\begin{array}{l}15 \text { per adolescent ages } \\
10-19 \text { years }\end{array}$ & $\begin{array}{l}9 \text { per adolescent } \\
\text { ages } 10-19 \text { years }\end{array}$ & 880 & 2,700 \\
\hline
\end{tabular}

Source: Fernandes and Aurino 2017 (chapter 25 in this volume); Horton and others 2017 (chapter 26 in this volume).

Note: - = not available; Gavi = Gavi, the Vaccine Alliance; HPV = human papillomavirus; ITN = insecticide-treated bednet. The total cost of the school-age package is about US $\$ 10$ per child in the 5-14 years age group and about US\$9 per adolescent in the 10-19 years age group. Compared with per capita public expenditures on health in 2013 of about US\$31, this does not seem unreasonable, but it is high for low-income countries, which spent only US\$14 per capita on health in 2013. 
than the increments sought for education or for the health programs for children under five years of age.

The single most costly component is school meals, which account for almost half of the additional investment required. We have argued earlier that this is a special case and is neither paid for by the Ministry of Health nor primarily aimed at improving health. It is standard in DCP3 to distinguish between interventions within the health sector and those delivered and financed outside the health sector. School meals, although part of the health package, are intersectoral in origin. For this reason, table 1.1 shows the costs with and without school meals. See also volume 9 for further discussion of this issue (chapter 2 [Watkins, Nugent, and others 2018]).

Taken together, these analyses suggest two important conclusions for investing in health in the 5 to 19 age group. It is apparent that education investments dominate all other public investments in human development during the first two decades of life. Using our estimates of current expenditure, the current costs of providing access in low- and lower-middle-income countries to basic education and a health care services package for under-fives (including maternal and newborn health) are US\$206 billion and US\$28.6 billion, respectively. The cost of the additional essential health and development packages for those ages 5-19 years are between US\$1.4 billion and US\$3.4 billion, respectively. Given that the latter two health and development investments underpin those in education, it seems difficult to justify investing in education without making the complementary investments in health and human development for this age group, especially given the comparatively low cost of the health and development packages. The modest cost of the two packages suggests that scaling up the health packages for those ages 5-19 is therefore a high return and low-cost investment that addresses the most pressing development needs throughout the first two decades of life.

\section{HEALTH AND EDUCATION: TWO SIDES OF THE SAME COIN}

This volume makes a strong case for providing both education and health services during middle childhood and adolescence. The view that education and health are separate silos in human development reflects an administrative and bureaucratic reality but does not best serve the needs of the growing child and adolescent. The common sense view that growing children need both health and education-mens sana in corpore sano-is supported by the evidence for strong links between health outcomes and educational attainment (Bundy, Schultz, and others 2017, chapter 20 in this volume; Plaut and others 2017, chapter 22 in this volume), and between educational attainment and health outcomes (Pradhan and others 2017). Years of schooling and quality of schooling (as measured by standardized test scores) reduce mortality rates in adults and children. Chapter 30 of this volume (Pradhan and others 2017) reports research that has recently incorporated both adult mortality outcomes and education quality into the literature. If rates of return to educational investments are recalculated to take into account reasonable estimates of the value of reducing mortality, the returns to education increase by about one-third. For example, in lower-middle-income countries, the estimated internal rate of return to one additional year of education increases from 7.0 percent to 9.3 percent if the effect of education on mortality is included. In this volume we explore both of these directions of influence.

\section{Health, Education, and Social Outcomes}

Exposing young children to drought and social shocks in Zimbabwe was shown to adversely affect height in adolescence, which, in turn, adversely affected schooling (Alderman, Hoddinott, and Kinsey 2006). Effect sizes were large: if individuals had reached median height for age, they would have been 3.4 centimeters taller, started school six months earlier, and have achieved an additional 0.85 years of schooling. There are also some trials in low- and middle-income countries that indicate impact: for example, young children with better diets in the Philippines did better in school than their lessadvantaged siblings (Glewwe, Jacoby, and King 2001). Micronutrient deficiencies (particularly of iodine and iron, both known to affect cognition) have adverse effects on grade repetition and scores on cognitive tests (surveyed by Alderman and Bleakley 2013). In contrast, a recent systematic review, largely in LMICs, provides a more ambiguous picture of the impact of school-based interventions (Snilstveit and others 2015). We now recognize that development outcomes are crucially dependent upon the age-specific timing of intervention and upon the duration of follow-up. This is an area where longitudinal studies are particularly important but are currently rare. Chapter 7 of this volume (Alderman and others 2017) uses the lifecycle approach to assess the benefit-cost ratios of interventions in nutrition and child development in LMICs where nutrition is a risk factor, with a focus on the first five years of life. Chapter 12 (Drake and others 2017) summarizes the effects of school feeding programs (which alleviate hunger) on improved school attendance and test scores. 
Chapter 27 (Nandi and others 2017) discusses the longterm human capital and economic benefits of early-life interventions.

Chapter 14 in this volume (Brooker and others 2017) reviews the effect of malaria on education. Randomized controlled trials found that treatment of malaria reduced absenteeism and that treatment provided in childhood improved schooling attainment in adolescence; in two countries, schoolchildren receiving malaria prophylaxis had better attention spans. Chapter 13 (Bundy, Appleby, and others 2017) and chapter 29 (Ahuja and others 2017) emphasize the importance of deworming for education.

Uncertainty about the appropriate metrics is one reason the scale of the contribution of ill health to unrealized cognitive attainment, and hence learning, is poorly understood. Both the WHO and IHME estimate the effect of ill health on cognition using a threshold approach, typically the proportion of the affected population that scores below some threshold-for example, an intelligence quotient (IQ) of 75, indicative of severe cognitive disability. A more informative metric would be some population level metric of the extent to which individuals reach their cognitive potential, analogous to the assessment of anthropometric status. There is also a need for an impact model that takes into account the overlapping benefits of multiple interventions. Given the secular trend for IQ scores to drift upward (Flynn 2007), it might be helpful to estimate the extent to which improved health will contribute to the achievement of cognitive potential.

\section{Education and Health Outcomes}

An extensive literature documents the correlation between higher levels of education and lower levels of mortality, illness, and health risk. The earliest data showed no association: in the late nineteenth century, mortality levels of individuals with high education were no lower than those of individuals with little education. However, by the early twentieth century, U.S. census data revealed a strong association between health and education. This transition has been attributed to the scientific revolution launched by Koch and Pasteur with the germ theory of disease, which gave households and states practicable means of interrupting the transmission of infectious disease (Preston and Haines 1991). Without such knowledge, an educated person could do little more than could an illiterate compatriot, but the more educated person learned about and adopted the newly available science from Europe much more quickly. This conclusion has close parallels with research on the value of education to economic productivity: in the presence of access to new markets, new seeds, or new crops, educated farmers quickly surpass illiterate farmers, but in closed, stagnant economies, formal education confers no advantage (Schultz 1993).

Rapidly changing knowledge and greater access to powerful drugs and vaccines should have led education to play an important role in halving the mortality rate for adolescents and adults 15-60 years of age around the world in the half century since 1970. But rates of decline varied markedly from country to country. Why such variation? For child mortality, variation in income growth explained a modest amount of cross-country differences (Jamison, Murphy, and Sandbu 2016). The number of available medical professionals explained more, and the pace at which some countries were able to adopt powerful and low-cost child survival technologies explained even more. About 9 percent of the reduction in child mortality from 1970 to 2000 in LMICs resulted from increased levels of education, as discussed in chapter 30 (Pradhan and others 2017).

Similarly, strong controls for country-specific effects in both the level and the rate of change of child and adult mortality resulted in education effects that were quantitatively and statistically highly significant (Pradhan and others 2017, chapter 30 in this volume). This study suggests that education's effects on adult mortality rates are about the same as the effects on child mortality (around 2-3 percent reduction per additional year of education and per one standard deviation improvement in test scores). If rates of return to educational investments are recalculated to take into account reasonable estimates of the value of mortality reduction, the returns to education increase by about one-third. For example, in lowermiddle-income countries, the estimated internal rate of return to one additional year of education increases from 7.0 to 9.3 percent if the effect of education on mortality is included.

\section{RESEARCH AND DEVELOPMENT PRIORITIES}

The analyses presented here suggest some priorities for future research, with a focus on longer-term periods of observation that will capture developmental outcomes, assessment of multiple and complementary interventions, and, most important, a greater focus on children in middle childhood and adolescents. Specifically, future research should take into account the following issues.

1. Collect better data on health and development needs in the 5 to 21 age range. As shown in annex $1 \mathrm{~A}$, there has been a strong research focus on the health and development of children under five and a concomitant 
relative absence of research on the needs of children in middle childhood and adolescence. There is a particular lack of information on children five to nine years of age.

2. Pilot and evaluate packages of interventions for middle childhood and adolescence. The packages proposed in this volume are based on the published literature for the individual interventions. In many cases, the evidence is partial and overly reliant on experiences in high-income countries. This suggests a need to carefully pilot and evaluate the packages under local circumstances before going to scale.

3. Conduct more long-term longitudinal studies. Most of the available analyses are too short term (typically less than a year) to provide useful guidance on development, which is inherently a long-term issue. To be useful, studies need to track outcomes over multiple years. A key question concerns the relative importance to development outcomes of intervention at different phases.

4. Measure multiple outcomes of interventions. Studies generally assess a single or a few outcomes, whereas the focus of development is inherently multisectoral and multifactorial. In particular, more studies are needed that simultaneously assess physical growth and cognitive development to assess the mutual benefits for health and education outcomes.

5. Track mortality beyond age 5 . The new evidence that mortality is higher than recognized in those ages 5-14 indicates a need for more clarity about appropriate survival interventions for this age group. A starting point in middle childhood would be to assess the applicability of interventions that have proved successful in reducing the mortality of children under five; however, the causes of death are likely to be quite different for older adolescents, in particular.

6. Examine the social dimensions of intervention in childhood and adolescence. The social ecology of children's lives is poorly understood, especially in low- and lower-middle-income countries. There is a specific need for locally relevant research on the importance of families and teachers and of the gender context.

7. Understand biological differences as a development issue. There are sex differences in growth and development. For example, pubertal development differs by sex, so the timing of the growth spurt and the accompanying physiological changes also happen on a different timeline and scale. We now know that large differences are also apparent in brain development, yet we know little of the implications for behavioral intervention.
8. Estimate the scale of the contribution of disability to development. Children with disabilities are less able to benefit from prosperity, and disability remains a largely hidden topic. This is particularly true of mental health challenges in low-income countries and LMICs, and even more so of behavioral and social challenges, including autism. IHME estimates suggest that one in six children ages 5-19 years is severely or very severely disabled.

In reviewing these research issues, two short-term responses could be quickly implemented if there is to be a serious effort to understand the health and development needs of middle childhood and adolescence: (1) support existing longitudinal studies to define returns on interventions in middle childhood and adolescence, and (2) extend current mortality surveillance tools to include those ages $5-19$ years.

In this volume, we propose intervening during ages that have not traditionally been given policy priority, especially in low-income countries. Developing an appropriate response will require stronger investment in implementation research that addresses the specific needs of middle childhood and adolescence. A potential way to move forward efficiently would be to expand the age range and interventions explored in current research models designed to assess developmental outcomes longitudinally. Examples include the 20-year-old Matlab Health and Socioeconomic Survey in Bangladesh; the 40-year-old Medical Research Council Keneba study in The Gambia; and the 15-yearold Young Lives studies in Ethiopia, India, Peru, and Vietnam, all of which are still ongoing. One of the key questions might be, what intervention is necessary to achieve remediation for children who slipped through the early safety net?

The burden of mortality and serious disease in the 5-19 age group is substantially higher than had been realized. During the Millennium Development Goals era, there was notable success in reducing under-5 mortality, and a key contributor was the creation of two new mechanisms for tracking mortality in children in this age group: the United Nations Interagency Group for Child Mortality Estimation, which provides current child mortality estimates through the Child Mortality Estimation database; and the Child Health Epidemiology Reference Group, which develops improved evidence on the causes of child mortality. If the world is to be similarly successful in addressing mortality in older children, there will need to be a similarly strong evidence-based approach to mortality in ages beyond five. This could be 
achieved if both of these groups extended the age range up to 21 and engaged with the research and public health communities working with these older age groups.

\section{CONCLUSIONS}

Although the current investment focus on the first 1,000 days of human development is necessary, it is not enough. The narrow focus on investing in health in the earliest childhood years underserves our children and adolescents by failing to support their development at other critical phases during the first two decades of life and by failing to secure the early gains. This unbalanced approach has not only resulted in a neglect of health service provision after the first 1,000 days but has also deflected research away from middle childhood and adolescence.

The issue is not that the first 1,000 days are less important than previously thought, but rather that the subsequent 7,000 days before the child reaches age 21 have much greater importance than has been recognized. Based largely on cost-effectiveness and benefit-cost analyses, we have identified two essential packages of interventions that together can help address these health and development demands in middle childhood and adolescence. A school-age package, largely built around school-based delivery, can address many of the needs during middle childhood and the adolescent growth spurt. An adolescence package, built both around the school and around access to nonstigmatizing, affordable, and confidential health care, can help further address the needs during the adolescent growth spurt and the very particular needs of later adolescence. The purposes of the two packages overlap, as do the age ranges of the target populations, and so both packages are required to support development through middle childhood and adolescence. It is important to recognize that the school and the education sector are key participants in these processes, both by providing an infrastructure for delivery and, just as important, by providing the learning, understanding, and life skills that have contributed, for example, about 30 percent of the observed decline in maternal mortality since 1990.

There are powerful opportunities for synergy between health and education that are currently underexploited. The school and the education sector should be recognized as key participants in promoting health, both by providing an infrastructure for delivery and, just as important, by providing the learning, understanding, and life skills that, for example, have contributed about 30 percent of the observed decline in maternal mortality since 1990 . However, the health of school-age children and adolescents, especially in low- and lower-middle-income countries, is an important determinant of education outcomes, having consequences for both education access and learning. The analyses presented here for the first 8,000 days indicate that investments in health leverage education outcomes, and investments in education leverage health.

The current world view is that education is a high priority and that the MDGs have helped ensure nearuniversal access to free primary education that is free at the point of delivery. One of the new Sustainable Development Goals is to achieve the same for secondary education. There is also increasing recognition that the RMNCH (reproductive, maternal, newborn and child health) demands of the 1,000 days should also be viewed as a high priority. Here we argue that, for similar reasons, the incremental costs of addressing health and development needs during middle childhood and adolescence should be viewed in the same way. Our calculations suggest that the proposed essential packages are a practical and affordable investment, even for LMICs. Based on current expenditures world-wide in LMICs, the annual cost of providing access to health care for children under five is US $\$ 28.6$ billion, and the cost of providing primary education is US\$206 billion. For the same countries, the estimated incremental cost of the essential health and development packages for ages 5 to 19 would add between US $\$ 1.4$ billion and US\$3.4 billion. This is a small increment to leverage the existing investments in early childhood and education and to secure the health and development of the next generation. Given the current levels of development assistance and domestic investment in both the first 1,000 days and in education, there would seem to be a strong economic case for leveraging these investments with critical, but more modest, health investments during the next 7,000 days, with benefits for equity, for realizing individual potential, and for maximizing the opportunities for the next generation.

The implication is that public policy needs to align with parental commitments and to the commitment to addressing health, development, and education through the first two decades of life. More countries already emphasize the social and legal importance of the 21st birthday, and our analyses suggest that it is necessary and affordable for all countries to translate that commitment into practical investments in middle childhood and adolescence. 


\section{ANNEX}

The annex to this chapter is as follows. It is available at http://www.dcp-3.org/CAHD.

- Annex 1A. Analysis of Published Literature Describing Health and Mortality, Ages 0-19 Years

\section{NOTE}

World Bank Income Classifications as of July 2014 are as follows, based on estimates of gross national income (GNI) per capita for 2013:

- Low-income countries (LICs) $=$ US $\$ 1,045$ or less

- Middle-income countries (MICs) are subdivided:

a) lower-middle-income $=$ US $\$ 1,046$ to US $\$ 4,125$

b) upper-middle-income (UMICs) $=$ US $\$ 4,126$ to US $\$ 12,745$

- High-income countries (HICs) $=$ US $\$ 12,746$ or more.

\section{REFERENCES}

Ahuja, A., S. Baird, J. Hamory Hicks, M. Kremer, and E. Miguel. 2017. "Economics of Mass Deworming Programs." In Disease Control Priorities (third edition): Volume 8, Child and Adolescent Health and Development, edited by D. A. P. Bundy, N. de Silva, S. Horton, D. T. Jamison, and G. C. Patton. Washington, DC: World Bank.

Alderman, H., J. Behrman, P. Glewwe, L. Fernald, and S. Walker. 2017. "Evidence of Impact on Growth and Development of Interventions during Early and Middle Childhood." In Disease Control Priorities (third edition): Volume 8, Child and Adolescent Health and Development, edited by D. A. P. Bundy, N. de Silva, S. Horton, D. T. Jamison, and G. C. Patton. Washington, DC: World Bank.

Alderman, H., and H. Bleakley. 2013. "Child Health and Educational Outcomes." In Education Policy in Developing Countries, edited by P. Glewwe, 107-36. Chicago, IL: University of Chicago Press.

Alderman, H., J. Hoddinott, and B. Kinsey. 2006. "Long Term Consequences of Early Childhood Malnutrition." Oxford Economic Papers 58 (3): 450-74.

Andersen, S. L., and M. H. Teicher. 2008. "Stress, Sensitive Periods and Maturational Events in Adolescent Depression." Trends in Neuroscience 31 (4): 183-91.

Babigumira, J. B., H. Gelband, and L. P. Garrison Jr. 2017. "Cost-Effectiveness of Strategies for Diagnosis and Treatment of Febrile Illness in Children.” In Disease Control Priorities (third edition): Volume 6, Major Infectious Diseases, edited by K. K. Holmes, S. Bertozzi, B. R. Bloom, and P. Jha. Washington, DC: World Bank.

Benzian, H., B. Varenne, N. Stauf, R. Garg, and B. Monse. 2017. "Promoting Oral Health through Programs in Middle Childhood and Adolescence." In Disease Control Priorities (third edition): Volume 8, Child and Adolescent Health and Development, edited by D. A. P. Bundy, N. de Silva, S. Horton, D. T. Jamison, and G. C. Patton. Washington, DC: World Bank.

Black, M., A. Gove, and K. A. Merseth. 2017. "Platforms to Reach Children in Early Childhood.” In Disease Control Priorities (third edition): Volume 8, Child and Adolescent Health and Development, edited by D. A. P. Bundy, N. de Silva, S. Horton, D. T. Jamison, and G. C. Patton. Washington, DC: World Bank.

Black, R., R. Laxminarayan, M. Temmerman, and N. Walker, editors. 2015. Disease Control Priorities (third edition): Volume 2, Reproductive, Maternal, Newborn, and Child Health. Washington, DC: World Bank.

Black, R., N. Walker, R. Laxminarayan, and M. Temmerman. 2015. "Reproductive, Maternal, Newborn, and Child Health: Key Messages of This Volume." In Disease Control Priorities (third edition): Volume 2, Reproductive, Maternal, Newborn, and Child Health, edited by R. Black, R. Laxminarayan, M. Temmerman, and N. Walker. Washington, DC: World Bank.

Blakemore, S. J., and K. L. Mills. 2014. "Is Adolescence a Sensitive Period for Sociocultural Processing?" Annual Review of Psychology 65 (January): 187-207.

Blank, L., S. Baxter, E. Goyder, P. Naylor, L. Guillaume, and others. 2010. "Promoting Well-Being by Changing Behaviour: A Systematic Review and Narrative Synthesis of the Effectiveness of Whole Secondary School Behavioural Interventions." Mental Health Review Journal 15 (2): 43-53.

Brooker, S., S. Clarke, D. Fernando, C. Gitonga, J. Nankabirwa, D. Schellenberg, and others. 2017. "Malaria in Middle Childhood and Adolescence." In Disease Control Priorities (third edition): Volume 8, Child and Adolescent Health and Development, edited by D. A. P. Bundy, N. de Silva, S. Horton, D. T. Jamison, and G. C. Patton. Washington, DC: World Bank.

Brown, D. S., X. Fang, and C. S. Florence. 2011. "Medical Costs Attributable to Child Maltreatment: A Systematic Review of Short- and Long-Term Effects." American Journal of Preventive Medicine 41 (6): 627-35.

Bundy, D. A. P., L. Appleby, M. Bradley, K. Croke, D. Hollingsworth, and others. 2017. "Mass Deworming Programs in Middle Childhood and Adolescence." In Disease Control Priorities (third edition): Volume 8, Child and Adolescent Health and Development, edited by D. A. P. Bundy, N. de Silva, S. Horton, D. T. Jamison, and G. C. Patton. Washington, DC: World Bank.

Bundy, D. A. P., and S. Horton. 2017. "Impact of Interventions on Health and Development during Childhood and Adolescence: A Conceptual Framework." In Disease Control Priorities (third edition): Volume 8, Child and Adolescent Health and Development, edited by D. A. P. Bundy, N. de Silva, S. Horton, D. T. Jamison, and G. C. Patton. Washington, DC: World Bank.

Bundy, D. A. P., L. Schultz, B. Sarr, L. Banham, P. Colenso, and L. Drake. 2017. "The School as a Platform for Addressing Health in Middle Childhood and Adolescence." In Disease 
Control Priorities (third edition): Volume 8, Child and Adolescent Health and Development, edited by D. A. P. Bundy, N. de Silva, S. Horton, D. T. Jamison, and G. C. Patton. Washington, DC: World Bank.

Carnerio, I., A. Roca-Feltrer, J. T. Griffin, L. Smith, M. Tanner, and others. 2010. "Age-Patterns of Malaria Vary with Severity, Transmission Intensity and Seasonality in SubSaharan Africa: A Systematic Review and Pooled Analysis." PLos One 5: e8988.

Ceesay, S. J., C. Casals-Pascual, J. Erskine, S. E. Anyam No. O. Duah, and others. 2008. "Changes in Malaria Indices between 1999 and 2007 in The Gambia: A Retrospective Analysis." The Lancet 372: 1545-54.

CDC (Centers for Disease Control and Prevention). 2015. THRIVES: A Global Technical Package to Prevent Violence against Children. Atlanta, GA: Division of Violence Prevention, National Center for Injury Prevention and Control, CDC. https://stacks.cdc.gov/view/cdc/31482.

Chandra-Mouli, V., C. Lane, and S. Wong. 2015. "What Does Not Work in Adolescent Sexual and Reproductive Health: A Review of Evidence on Interventions Commonly Accepted as Best Practices." Global Health Science and Practice 3 (3): 333-40.

Crookston, B. T., W. Schott, S. Cueto, K. A. Dearden, P. Engle, and others. 2013. "Postinfancy Growth, Schooling, and Cognitive Achievement: Young Lives." American Journal of Clinical Nutrition 98 (6): 1555-63.

Currie, J., and C. S. Widom. 2010. "Long-Term Consequences of Child Abuse and Neglect on Adult Economic WellBeing." Child Maltreatment 15 (2): 111-20.

Dahl, R. E. 2004. "Adolescent Brain Development: A Period of Vulnerabilities and Opportunities." Keynote Address: Annals of the New York Academy of Sciences 1021: 1/22.

de Walque, D., L. Fernald, P. Gertler, and M. Hidrobo. 2017. "Cash Transfers and Child and Adolescent Development." In Disease Control Priorities (third edition): Volume 8, Child and Adolescent Health and Development, edited by D. A. P. Bundy, N. de Silva, S. Horton, D. T. Jamison, and G. C. Patton. Washington, DC: World Bank.

Drake, L., M. Fernandes, E. Aurino, J. Kiamba, B. Giyosa, and others. 2017. "School Feeding Programs in Middle Childhood and Adolescence." In Disease Control Priorities (third edition): Volume 8, Child and Adolescent Health and Development, edited by D. A. P. Bundy, N. de Silva, S. Horton, D. T. Jamison, and G. C. Patton. Washington, DC: World Bank.

Durlak, J. A., R. P. Weissberg, and A. B. Dymnicki. 2011. "The Impact of Enhancing Students' Social and Emotional Learning: A Meta-Analysis of School-Based Universal Interventions." Child Development 82 (1): 405-32.

Elvik, R., A. Hoye, T. Vaa, and M. Sorensen. 2009. The Handbook of Road Safety Measures (second edition). Bingley, U.K.: Emerald Group Publishing Limited.

Fang, X., D. A. Fry, K. Ji, D. Finkelhore, J. Chen, and others. 2015. "The Burden of Child Maltreatment in China: A Systematic Review." Bulletin of the World Health Organization 93 (3): $176-85 c$.
Farahmand, F. K., K. E. Grant, A. J. Polo, and S. N. Duffy. 2011. "School-Based Mental Health and Behavioral Programs for Low-Income, Urban Youth: A Systematic and MetaAnalytic Review." Clinical Psychology 18 (4): 372-90.

Farrelly, M. C., B. R. Loomis, B. Han, J. Gfroerer, N. Kuiper, and others. 2013. "A Comprehensive Examination of the Influence of State Tobacco Control Programs and Policies on Youth Smoking." American Journal of Public Health 103 (3): 549-55.

Fernandes, M., and E. Aurino. 2017. "Identifying an Essential Package for School-Age Child Health: Economic Analysis." In Disease Control Priorities (third edition): Volume 8, Child and Adolescent Health and Development, edited by D. A. P. Bundy, N. de Silva, S. Horton, D. T. Jamison, and G. C. Patton. Washington, DC: World Bank.

Fitzpatrick, C., U. Nwankwo, E. Lenk, S. J. de Vlas, and D. A. P. Bundy. 2017. "An Investment Case for Ending Neglected Tropical Diseases." In Disease Control Priorities (third edition): Volume 6, Major Infectious Diseases, edited by K. K. Holmes, S. Bertozzi, B. R. Bloom, and P. Jha. Washington, DC: World Bank.

Flynn, J. R. 2007. What Is Intelligence? Cambridge, U.K., and New York: Cambridge University Press.

Galloway, R. 2017. "Global Nutrition Outcomes at Ages 5 to 19." In Disease Control Priorities (third edition): Volume 8, Child and Adolescent Health and Development, edited by D. A. P. Bundy, N. de Silva, S. Horton, D. T. Jamison, and G. C. Patton. Washington, DC: World Bank.

Gertler, P., J. Heckman, R. Pinto, A. Zanolini, C. Vermeersch, and others. 2014. "Labor Market Returns to an Early Childhood Stimulation Intervention in Jamaica." Science 344 (6187): 998-1001.

Glewwe, P., H. Jacoby, and E. King. 2001. "Early Childhood Nutrition and Academic Achievement: A Longitudinal Analysis." Journal of Public Economics 81 (3): 345-68.

Goddings, A., K. L. Mills, L. S. Clasen, J. N. Giedd, R. M. Viner, and S. Blakemore. 2014. "The Influence of Puberty on Subcortical Brain Development." NeuroImage 88: 242-51.

Graham, N., L. Schultz, S. Mitra, and D. Mont. 2017. "Disability in Middle Childhood and Adolescence." In Disease Control Priorities (third edition): Volume 8, Child and Adolescent Health and Development, edited by D. A. P. Bundy, N. de Silva, S. Horton, D. T. Jamison, and G. C. Patton. Washington, DC: World Bank.

Grantham-McGregor, S. M., C. A. Powell, S. P. Walker, and J. H. Himes. 1991. "Nutritional Supplementation, Psychosocial Stimulation, and Mental Development of Stunted Children: The Jamaican Study." The Lancet 338 (8758): 1-5.

Grigorenko, E. 2017. "Brain Development: The Effect of Interventions on Children and Adolescents." In Disease Control Priorities (third edition): Volume 8, Child and Adolescent Health and Development, edited by D. A. P. Bundy, N. de Silva, S. Horton, D. T. Jamison, and G. C. Patton. Washington, DC: World Bank.

Heckmann, J. J. 2011. "Effective Child Development Strategies." In The Pre-K Debates: Current Controversies and Issues, 
edited by E. Zigler, W. S. Gilliam, and W. S. Barnett. Baltimore, MD: Paul H. Brookes Publishing.

Hill, K., L. Zimmerman, and D. T. Jamison. 2017. "Mortality at Ages 5 to 19: Levels and Trends, 1990-2010." In Disease Control Priorities (third edition): Volume 8, Child and Adolescent Health and Development, edited by D. A. P. Bundy, N. de Silva, S. Horton, D. T. Jamison, and G. C. Patton. Washington, DC: World Bank.

Horton, S., and M. Black. 2017. "Identifying an Essential Package for Early Childhood Development: Economic Analysis." In Disease Control Priorities (third edition): Volume 8, Child and Adolescent Health and Development, edited by D. A. P. Bundy, N. de Silva, S. Horton, D. T. Jamison, and G. C. Patton. Washington, DC: World Bank.

Horton, S., J. Waldfogel, E. De la Cruz Toledo, J. Mahon, and J. Santelli. 2017. "Identifying an Essential Package for Adolescent Health: Economic Analysis." In Disease Control Priorities (third edition): Volume 8, Child and Adolescent Health and Development, edited by D. A. P. Bundy, N. de Silva, S. Horton, D. T. Jamison, and G. C. Patton. Washington, DC: World Bank.

International Commission on Financing Global Education Opportunity. 2016. The Learning Generation: Investing in Education for a Changing World. New York: International Commission on Financing Global Education Opportunity. http://report.educationcommission.org.

Jamison, D. T., J. G. Breman, A. R. Measham, G. Alleyne, M. Claeson, D. B. Evans, P. Jha, A. Mills, and P. Musgrove, editors. 2006. Disease Control Priorities in Developing Countries (second edition). Washington, DC: Oxford University Press and World Bank.

Jamison, D. T., W. Mosley, A. R. Measham, and J. Bobadilla, editors. 1993. Disease Control Priorities in Developing Countries (first edition). New York: Oxford University Press.

Jamison, D. T., S. M. Murphy, and M. E. Sandbu. 2016. "Why Has Under-5 Mortality Decreased at Such Different Rates in Different Countries?" Journal of Health Economics 48 (July): 16-25.

Jukes, M. C. H., L. J. Drake, and D. A. P. Bundy. 2008. Leveling the Playing Field: School Health Nutrition for All. Oxfordshire, U.K.: CABI Publishing.

LaMontagne, D. S., T. Cernushi, A. Yabuku, P. Bloem, D. Watson-Jones, and J. Kim. 2017. "School-Based Delivery of Vaccines to 5 to 19 Year Olds." In Disease Control Priorities (third edition): Volume 8, Child and Adolescent Health and Development, edited by D. A. P. Bundy, N. de Silva, S. Horton, D. T. Jamison, and G. C. Patton. Washington, DC: World Bank.

Lassi, Z., A. Moin, and Z. Bhutta. 2017. "Nutrition in Middle Childhood and Adolescence." In Disease Control Priorities (third edition): Volume 8, Child and Adolescent Health and Development, edited by D. A. P. Bundy, N. de Silva, S. Horton, D. T. Jamison, and G. C. Patton. Washington, DC: World Bank.

Masquelin, B. 2017. "Global, Regional, and National Levels and Trends in Mortality among Older Children (5-9) and Young Adolescents (10-14) from 1990-2015.” Paper prepared for UN Inter-agency Group for Child Mortality Estimation (IGME), UNICEF, New York.

Mock, C. N., O. Kobusingye, R. Nugent, and K. Smith, editors. 2017. Disease Control Priorities (third edition): Volume 7, Injury Prevention and Environmental Health. Washington, DC: World Bank.

Mokdad, A., M. H. Forouzanfar, F. Daoud, A. A. Mokdad, C. El Bcheraoui, and others. 2016. "Global Burden of Diseases, Injuries, and Risk Factors for Young People's Health During 1990-2013: A Systematic Analysis for the Global Burden of Disease Study 2013." The Lancet 387: 2383-401.

Murray, N. G., B. J. Low, C. Hollis, A. W. Cross, and S. M. Davis. 2007. "Coordinated School Health Programs and Academic Achievement: A Systematic Review of the Literature." Journal of School Health 77 (9): 589-600.

Nandi, A., J. R. Behrman, S. Bhalotra, A. B. Deolalikar, and R. Laxminarayan. 2017. "The Human Capital and Productivity Benefits of Early Childhood Nutritional Interventions." In Disease Control Priorities (third edition): Volume 8, Child and Adolescent Health and Development, edited by D. A. P. Bundy, N. de Silva, S. Horton, D. T. Jamison, and G. C. Patton. Washington, DC: World Bank.

Noor A. M., D. K. Kinyoki, C. W. Mundia, et al. 2014. “The Changing Risk of Plasmodium Falciparum Malaria Infection in Africa: 2000-10: A Spatial and Temporal Analysis of Transmission Intensity." The Lancet 383: 1739-47.

Norman, R. E., M. Byambaa, R. De, A. Butchart, J. Scott, and others. 2012. "The Long-Term Health Consequences of Child Physical Abuse, Emotional Abuse, and Neglect: A Systematic Review and Meta-Analysis." PLoS Medicine 9 (11): 1-31.

O’Meara, W. P., P. Bejon, T. W. Mwangi, E. A. Okiro, N. Peshu, and others. 2008. "Effect of a Fall in Malaria Transmission on Morbidity and Mortality in Kilifi, Kenya." The Lancet 372 (9649): 1555-62.

Patton, G. C., P. Azzopardi, E. Kennedy, C. Coffey, and A. Mokdad. 2017. "Global Measures of Health Risks and Disease Burden in Adolescents." In Disease Control Priorities (third edition): Volume 8, Child and Adolescent Health and Development, edited by D. A. P. Bundy, N. de Silva, S. Horton, D. T. Jamison, and G. C. Patton. Washington, DC: World Bank.

Patton, G. C., S. M. Sawyer, J. S. Santelli, D. A. Ross, R. Afifi, and others. 2016. "Our Future: A Lancet Commission on Adolescent Health and Wellbeing." The Lancet 387 (10036): 2423-78.

Plaut, D., T. Hill, M. Thomas, J. Worthington, M. Fernandes, and N. Burnett. 2017. "Getting to Education Outcomes: Reviewing Evidence from Health and Education Interventions." In Disease Control Priorities (third edition): Volume 8, Child and Adolescent Health and Development, edited by D. A. P. Bundy, N. de Silva, S. Horton, D. T. Jamison, and G. C. Patton. Washington, DC: World Bank. 
Pradhan, E., E. M. Suzuki, S. Martínez, M. Schäferhoff, and D. T. Jamison. 2017. "The Effects of Education Quantity and Quality on Mortality." In Disease Control Priorities (third edition): Volume 8, Child and Adolescent Health and Development, edited by D. A. P. Bundy, N. de Silva, S. Horton, D. T. Jamison, and G. C. Patton. Washington, DC: World Bank.

Prentice, A. M., K. A. Ward, G. R. Goldberg, L. M. Jarjou, S. E. Moore, and others. 2013. "Critical Windows for Nutritional Interventions against Stunting." American Journal of Clinical Nutrition 97 (5): 911-18.

Preston, S., and M. Haines. 1991. Fatal Years: Child Mortality in Late Nineteenth Century America. Princeton, NJ: Princeton University Press.

Reavley, N., G. C. Patton, S. Sawyer, E. Kennedy, and P. Azzopardi. 2017. "Health and Disease in Adolescence." In Disease Control Priorities (third edition): Volume 8, Child and Adolescent Health and Development, edited by D. A. P. Bundy, N. de Silva, S. Horton, D. T. Jamison, and G. C. Patton. Washington, DC: World Bank.

Sarr, B., B. McMahon, F. Peel, M. Fernandes, D. A. P. Bundy, and others. 2017. "The Evolution of School Health and Nutrition in the Education Sector 2000-2015." Frontiers in Public Health. https://doi.org/10.3389/fpubh.2016.00271.

Schultz, T. W. 1993. Origins of Increasing Returns. Oxford, U.K.: Blackwell.

Shackelton, N., F. Jamal, R. M. Viner, K. Dickson, G. C. Patton, and C. Bonell. 2016. "School-Level Interventions to Promote Adolescent Health: Systematic Review of Reviews." Journal of Adolescent Health 58 (4): 382-96.

Snilstveit, B., J. Stevenson, D. Phillips, M. Vojtkova, E. Gallagher, and others. 2015. "Interventions for Improving Learning Outcomes and Access to Education in Low- and MiddleIncome Countries: A Systematic Review," Final Review. London: International Initiative for Impact Evaluation (3ie).

Snow, R. W., J. A. Omumbo, B. Lowe, C. S. Molyneaux, J. O. Obiero, and others. 1997. "Relation between Severe Malaria Morbidity in Children and Level of Plasmodium Falciparum Transmission in Africa." The Lancet 349 (9006): 1650-54.

Tanner, J.L. 1990. Fetus into Man: Physical Growth from Conception to Maturity. Cambridge, MA: Harvard University Press.

United Nations. 2015. Transforming Our World: The 2030 Agenda for Sustainable Development. New York: United Nations.

United Nations General Assembly. 1989. "Convention on the Rights of the Child." United Nations Treaty Series, volume 1577, United Nations, New York.
Verguet, S., A. K. Nandi, V. Filippi, and D. A. P. Bundy. 2017. "Postponing Adolescent Parity in Developing Countries through Education: An Extended Cost-Effective Analysis." In Disease Control Priorities (third edition): Volume 8, Child and Adolescent Health and Development, edited by D. A. P. Bundy, N. de Silva, S. Horton, D. T. Jamison, and G. C. Patton. Washington, DC: World Bank.

Viner, R. M., A. B. Allen, and G. C. Patton. 2017. "Puberty, Developmental Processes, and Health Interventions." In Disease Control Priorities (third edition): Volume 8, Child and Adolescent Health and Development, edited by D. A. P. Bundy, N. de Silva, S. Horton, D. T. Jamison, and G. C. Patton. Washington, DC: World Bank.

Viner, R. M., E. M. Ozer, S. Denny, M. Marmot, M. Resnick, and others. 2012. "Adolescence and the Social Determinants of Health.” The Lancet 379 (9826): 1641-52.

Watkins, K., D. A. P. Bundy, D. T. Jamison, F. Guenther, and A. Georgiadis. 2017. "Evidence of Impact on Health and Development of Intervention during Middle Childhood and School Age." In Disease Control Priorities (third edition): Volume 8, Child and Adolescent Health and Development, edited by D. A. P. Bundy, N. de Silva, S. Horton, D. T. Jamison, and G. C. Patton. Washington, DC: World Bank.

Watkins, D., R. Nugent, G. Yamey, H. Saxenian, C. N. Mock, and others. 2018. "Intersectoral Policies for Health." In Disease Control Policies (third edition): Volume 9, Disease Control Priorities: Improving Health and Reducing Poverty, edited by D. T. Jamison, R. Nugent, H. Gelbrand, S. Horton, P. Jha, R. Laxminarayan, and C. N. Mock. Washington, DC: World Bank.

World Bank. 1993. World Development Report 1993: Investing in Health. New York: Oxford University Press.

- 2006. World Development Report 2007: Development and the Next Generation. Washington, DC: World Bank.

WHO (World Health Organization). 2015. Guidelines for the Treatment of Malaria. 3rd ed. Geneva: WHO.

Wu, K. B. 2017. "Global Variation in Education Outcomes at Ages 5 to 19." In Disease Control Priorities (third edition): Volume 8, Child and Adolescent Health and Development, edited by D. A. P. Bundy, N. de Silva, S. Horton, D. T. Jamison, and G. C. Patton. Washington, DC: World Bank.

Zielinski, D. S. 2009. "Child Maltreatment and Adult Socioeconomic Well-Being." Child Abuse and Neglect 33 (10): 666-78. 